\title{
Distinct Features of Germinal Center Reactions in Macaques Infected by SIV or Vaccinated with a T-Dependent Model Antigen
}

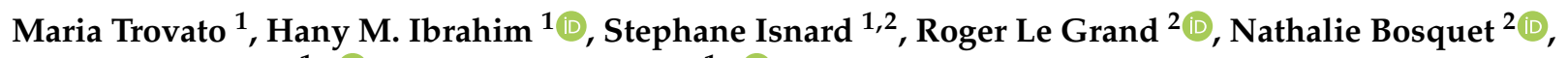 \\ Gwenoline Borhis ${ }^{1, *(1)}$ and Yolande Richard ${ }^{1, *(D)}$ \\ 1 Institut Cochin, Université de Paris, INSERM, CNRS, 75014 Paris, France; maria.trovato@ibbc.cnr.it (M.T.); \\ hanyibrahimeg@gmail.com (H.M.I.); stephane.isnard@mail.mcgill.ca (S.I.) \\ 2 Université Paris-Saclay, INSERM, CEA, Center for Immunology of Viral, Auto-Immune, Hematological and \\ Bacterial diseases (IMVA-HB/IDMIT), 92260 Fontenay-aux-Roses, France; roger.le-grand@cea.fr (R.L.G.); \\ nathalie.bosquet@cea.fr (N.B.) \\ * Correspondence: gwenoline.borhis@hotmail.fr (G.B.); yolande.richard@inserm.fr (Y.R.); \\ Tel.: +44-12-2391-8127 (G.B.); +33-1-4051-6585 (Y.R.)
}

Citation: Trovato, M.; Ibrahim, H.M.; Isnard, S.; Le Grand, R.; Bosquet, N.; Borhis, G.; Richard, Y. Distinct

Features of Germinal Center Reactions in Macaques Infected by SIV or Vaccinated with a

T-Dependent Model Antigen. Viruses 2021, 13, 263. https://doi.org/ $10.3390 /$ v13020263

Academic Editor: Herve J. A. Fleury Received: 18 December 2020

Accepted: 4 February 2021

Published: 9 February 2021

Publisher's Note: MDPI stays neutral with regard to jurisdictional claims in published maps and institutional affiliations.

Copyright: (c) 2021 by the authors. Licensee MDPI, Basel, Switzerland. This article is an open access article distributed under the terms and conditions of the Creative Commons Attribution (CC BY) license (https:/ / creativecommons.org/licenses/by/ $4.0 /)$.

\begin{abstract}
B-cell follicles constitute large reservoirs of infectious HIV/SIV associated to follicular dendritic cells and infecting follicular helper $\left(\mathrm{T}_{\mathrm{FH}}\right)$ and regulatory $\left(\mathrm{T}_{\mathrm{FR}}\right) \mathrm{T}$-cells in germinal centers (GCs). Thus, follicular and GC B-cells are persistently exposed to viral antigens. Despite recent development of potent HIV immunogens, numerous questions are still open regarding GC reaction during early HIV/SIV infection. Here, we dissect the dynamics of B- and T-cells in GCs of macaques acutely infected by SIV (Group SIV ${ }^{+}$) or vaccinated with Tetanus Toxoid (Group TT), a T-dependent model antigen. Systemic inflammation and mobilization of antigen-presenting cells in inguinal lymph nodes and spleen are lower in Group TT than in Group SIV ${ }^{+}$. Despite spleen GC reaction of higher magnitude in Group SIV ${ }^{+}$, the development of protective immunity could be limited by abnormal helper functions of $\mathrm{T}_{\mathrm{FH}}$ massively polarized into $\mathrm{T}_{\mathrm{FH} 1}$-like cells, by inflammation-induced recruitment of fCD8 (either regulatory or cytotoxic) and by low numbers of $\mathrm{T}_{\mathrm{FR}}$ limiting $\mathrm{T}_{\mathrm{FH}} / \mathrm{T}_{\mathrm{FR}}$ competition for high affinity B-cells. Increased GC B-cells apoptosis and accumulation of CD21 ${ }^{\text {lo }}$ memory B-cells, unable to further participate to GC reaction, likely contribute to eliminate SIV-specific B-cells and decrease antibody affinity maturation. Surprisingly, functional GCs and potent TT-specific antibodies develop despite low levels of CXCL13.
\end{abstract}

Keywords: B-cells; SIV; GC; $\mathrm{T}_{\mathrm{FH}}$; CXCL10; CXCL13; BAFF; memory B-cells

\section{Introduction}

Various B-cell abnormalities associated with pathogenic HIV infection evidence several biases in the generation and function of virus-specific, post-germinal center (GC) effector B-cells [1,2]. In physiological settings, GC represents a unique place where B-cells stimulated by T-dependent (TD) antigens (Ags) undergo a complex and dynamic process of expansion and selection, allowing the generation of Ag-specific long-lived effectors: resting memory $\left(\mathrm{RM}, \mathrm{CD} 21^{+} \mathrm{CD} 27^{+}\right) \mathrm{B}$-cells and plasma blasts (PBs) [3-5]. Memory B-cells and PBs which ensure long-term protection against pathogens fail to cover this role during HIV/SIV infection, with progressive loss in HIV-specific and non-specific RM B-cells and HIV-specific antibodies (Abs) being globally inefficient in containing the viruses [1,2]. Indeed, if cross-neutralizing Abs with narrow breadth are frequently present during the first year of infection in HIV-infected individuals [6], most broadly neutralizing Abs (bNAbs) develop only after several years of infection and in a limited number of HIV-infected individuals [7]. A substantial fraction of $\mathrm{bNAbs}$ is produced by self/polyreactive B-cells which escape central or peripheral tolerance, as a consequence of chronic inflammation and exposure to viral Ags [8,9]. Nevertheless, these Abs frequently harbor high levels of somatic 
hyper-mutations in immunoglobulin (Ig) genes, arguing for their affinity maturation and selection in GC $[7,10,11]$. Studies of bNAbs have identified key vulnerability sites in the HIV-1 Envelope (Env) proteins [10,11], leading to the design of novel immunogens such as the SOSIP Trimers, biochemically stabilized native-like HIV-1 Env trimers that mimic the trimeric structure of HIV-1 spikes [12]. Recently, the BG505 SOSIP.664 trimers used as immunogen in optimized strategies of immunization succeeded in the development of robust Tier-2 NAbs in non-human primates (NHPs) $[13,14]$. In this animal model, neutralizing activities rapidly developed compared to neutralizing responses during HIV/SIV infection and were associated to high frequencies and quality of GC B-cells and follicular helper T-cells $\left(\mathrm{T}_{\mathrm{FH}}\right)$ following the first immunization. Beyond a possible broader recruitment of Env-specific B-cells, the absence of CD4 T-cell depletion might contribute to higher expansion of $\mathrm{T}_{\mathrm{FH}}$, with more potent helper activities. In contrast to macaques unimmunized or developing low titers of BG505-specific Tier-2 NAbs, those with high titers of NAbs showed significant protection from homologous SHIVBG505 challenge [15].

GCs are undoubtedly important dating sites where many cellular actors must dialogue appropriately to generate potent effector $\mathrm{B}$-cells and a protective $\mathrm{Ab}$ response. Cognate interactions between GC B-cells and $\mathrm{T}_{\mathrm{FH}}$ play a mandatory role in the positive selection and survival of B-cell clones expressing high affinity B-cell receptor (BCR) [5]. Present at elevated frequencies in GC during HIV /SIV infection, $\mathrm{T}_{\mathrm{FH}}$ frequently exhibit impaired helper functions and cytokine production during the chronic phase of infection [16]. However, we recently showed that $\mathrm{GC}_{\mathrm{FH}}$ can exert efficient helper functions during the acute phase of SIV infection [17]. Infected at higher frequencies than other memory CD4 ${ }^{+}$(mCD4) T-cells, GC $\mathrm{T}_{\mathrm{FH}}$ constitute a major reservoir of infectious virus in HIV-infected individuals, untreated or successfully treated by anti-retroviral therapy, as well as in elite controllers $[18,19]$. Follicular regulatory T-cells $\left(\mathrm{T}_{\mathrm{FR}}\right)$ expressing FOXP3 and endowed with immunosuppressive functions play a key role in regulating GC reactions through interactions with GC B-cells and $\mathrm{T}_{\mathrm{FH}}$, preventing the development of autoimmunity [20]. Heightened $\mathrm{T}_{\mathrm{FH}} / \mathrm{T}_{\mathrm{FR}}$ ratio is associated with the development of self-reactive Abs during chronic SIV infection [21]. However, $\mathrm{T}_{\mathrm{FR}}$ could also exert helper functions toward GC B-cells through IL10 provision [22]. Thus, the balance between immunosuppressive and helper functions of $\mathrm{T}_{\mathrm{FR}}$ could vary from one setting to another and over time in a given setting [23]. More recently, $\mathrm{T}_{\mathrm{FR}}$ were shown to be highly permissive to HIV infection, likely contributing to viral persistence in tissues [24]. Virions (infectious or not) released by $\mathrm{T}_{\mathrm{FH}}$ or $\mathrm{T}_{\mathrm{FR}}$ in GC are trapped into long-lived immune-complexes that decorate follicular dendritic cells (FDC) through binding to CD21 or Fc $\gamma$ R. These immune-complexes establish an even greater reservoir of HIV RNA that is highly resistant to anti-retroviral therapies [25]. In physiological settings, only GC B-cells that can displace Ags from FDC-associated immune-complexes, establish cognate interactions with $\mathrm{T}_{\mathrm{FH}}$ and receive appropriate cytokine signals from the GC microenvironment can differentiate into effector B-cells [5]. When chronic BCR occupancy and signaling occurs in GC B-cells with concomitant activation of Toll-like receptors (TLR) 7/9 and/or exposure to particular cytokines (IL21, IFN $\gamma$ ), this physiological process is disturbed and atypical (CD19 ${ }^{\mathrm{hi}} \mathrm{CD} 21^{\mathrm{lo}}$ ) memory B-cells are generated. These CD21 ${ }^{\text {lo }}$ memory B-cells frequently express inhibitory receptors (FcRL, PD1, CD22, CD85j) and activation markers (CD80, CD86, HLA-DR) at high level, and are mostly T-bet ${ }^{+}$and CD11 $\mathrm{c}^{+}[26]$. Although BCR signaling is altered in CD21 ${ }^{\text {lo }}$ B-cells, their capacity of Ag-presenting cells (APCs) is preserved [27-32]. Largely absent in healthy individuals, a subpopulation of $\mathrm{CD} 19^{\text {hi }} \mathrm{CD} 21^{\text {lo }}$ memory B-cells, first described as tissue-like memory (TLM, CD2 $1^{\mathrm{lo}} \mathrm{CD} 27^{\mathrm{lo}}$ ) B-cells in HIV-infected individuals [33], is also present in other settings [26,34]. In a mouse model of plasmodium infection, this population was shown to be short-lived pre-plasma blast producing pathogen-specific IgG [35]. In HIV-infected individuals, gp140-specific memory B-cells are not only enriched in TLM B-cells but also in activated memory (AM, CD21 $\left.{ }^{\mathrm{lo}} \mathrm{CD} 27^{+}\right)$B-cells [36]. This latter population also accumulates in blood of chronically HIV-infected individuals [33] and is expanded in lymphoid organs of SIV-infected macaques [17,37]. In a cohort of individuals 
receiving seasonal influenza vaccine, AM B-cells were shown to be enriched in Ag-specific B-cells and harbor features of post-GC B-cells, prone to plasma cell differentiation but refractory to GC re-entry [38]. This latter observation is consistent with low expression of CD62L, CXCR4 and CXCR5 but increased expression of CXCR3 on CD21 $1^{\text {lo }}$ memory B cells that preferentially guide them outside GC, as recently shown for T-bet ${ }^{+}$B-cells in lymph nodes (LNs) of HIV-infected patients [39]. Based on these data, IFN $\gamma$ overproduced by GC $\mathrm{T}_{\mathrm{FH}}$ during HIV/SIV infection might orchestrate the CD21 ${ }^{\mathrm{lo}} \mathrm{B}$-cell trafficking by impairing chemokine receptor expression.

In an attempt to elucidate GC B-cell and $\mathrm{T}_{\mathrm{FH}}$ dysfunctions in early HIV/SIV infection, here we propose a comprehensive study undertaken to compare GC reaction and humoral response in macaques either acutely infected by SIV or vaccinated with the Tetanus Toxoid (TT), a model TD vaccine Ag, known to elicit a lasting protective humoral response in humans and NHPs. The selection of TT as model Ag in this study relies on previous data in mice and humans, delineating the fate of TT-specific effector B-cells and Abs during primary and secondary immunization. After booster injection, TT-specific memory B-cells and plasma blasts/cells are widely distributed in human spleen, blood, tonsils and bone marrow [40] and helper T-cell response is polarized towards a Th1-cell phenotype as does the T-cell response to HIV-1 [41]. However, vaccination with TD Ags, including the TT vaccine or Env trimer-based vaccines, differs from HIV/SIV infection setting. First, SIV Ags, in particular Env, are dynamically modified over time during infection and displayed a broad set of epitopes whereas in the case of TT vaccine, TT Ag is only transiently present with a probably more stable set of epitopes. Additionally, a unique feature of HIV/SIV infection is CD4 T-cell depletion, particularly at the acute phase of infection. Nevertheless, it is worth underlining that young HIV-infected patients develop weaker antibody responses to vaccination with the trivalent seasonal influenza vaccine, despite virologic suppression and normal CD4 T-cell counts [42]. Apart, CD4 T-cell depletion, inflammation also lowers immune responses to Flu vaccine in HIV-infected and healthy individuals, with effector functions of blood B-cells and circulating $\mathrm{T}_{\mathrm{FH}}$ being both impaired [43]. Therefore, a comparison of the impact of early viral infection and vaccination on GC reaction requires further investigations to understand whether $\mathrm{GC}_{\mathrm{FH}}$ expansion and functions are comparable to those occurring in response to vaccination to a conventional TD Ag. We paid a particular attention to changes in GC B- and T-cell actors and their organization, as well as in effector B-cells in spleen and LNs. Circulating titers of SIV-specific and TT-specific Abs and inflammatory cytokines were assessed simultaneously.

\section{Materials and Methods}

\subsection{Animals, Infection and Immunization}

Sixteen adult male cynomolgus macaques (Macaca fascicularis), each weighing about $4 \mathrm{~kg}$ and aging about 34 to 45 months, were imported from Mauritius (SILABE, Strasbourg, France) and housed in the accredited animal facilities of the Infectious Disease Models and Innovative Therapies (IDMIT) Infrastructure (Fontenay-aux-Roses, France). NHPs were handled in accordance to national regulations (Commisariat à l'Energie Atomique et aux Energies Alternatives (CEA) Permit Number A 92-32-02), in compliance with Standards for Human Care and Use of Laboratory of the Office for Laboratory Animal Welfare under Assurance number A5826-01, and the European Directive (2010/63, recommendation $N^{\circ}$ 9). The study was approved by the Ministère de l'Education Nationale, de l'Enseignement Supérieur et de la Recherche (France) and the Comité d'Ethique en Expérimentation Animale $\mathrm{n}^{\circ} 44$ under the reference 2015121509045664 (APAFIS\#3178). Animals were fed standard monkey chow diet daily supplemented with fruit and vegetables and water ad libitum. Overall, animal health was daily monitored by care staff and veterinary personnel. The MHC haplotypes were determined (Table S1) and only animals negative for H6 haplotypes were used in this study. A first group of 10 macaques was intravenously inoculated with 5000 AID50 of a SIVmac251 stock [44] and followed for 28-30 days postinfection (pi) (Group SIV ${ }^{+}$). Experimental infection protocol and viral characterization of 
these SIV-infected macaques have been previously detailed in [17]. A second group of 6 macaques was immunized two times by intramuscular (IM) injection $(0.5 \mathrm{~mL}$ per injection, pre-filled syringe) of a commercial Tetanus Toxoid (TT) vaccine (Sanofi Pasteur SA, Lyon, France). Bilateral immunizations in upper thighs were used to increase the magnitude of the TT-specific response. The first immunization was performed 40 days prior to the boost. Macaques were then sacrificed 21 days post-boost (dpb) (Group TT). All animals were sedated with ketamine hydrochloride (Merial SAS, Villeurbanne, France) before immunization, sample collection and necropsy.

\subsection{Sample Collection and Processing}

For serum/plasma sampling and complete blood count, blood was collected into serum clot activator tubes or into K3-EDTA tubes (both from Greiner Bio-One, Frickenhausen, Germany) from Group SIV ${ }^{+}$before infection and at 2, 7, 10, 14, 21, 28/30 dpi; from Group TT before the prime and at 4, 7, 10, 14, 21, 28, 33 days post-priming, and before the boost (D0) and at 4, 7, 10,14, $21 \mathrm{dpb}$. Aliquots of serum and plasma samples were kept frozen at $-80^{\circ} \mathrm{C}$ until use. For both groups, blood cell formula and count, as well as hemoglobin concentration and hematocrit, were determined on K3-EDTA collected blood using an HMX A/L (Beckman Coulter, Villepinte, France). Spleen and inguinal LNs were immediately collected at necropsy under the supervision of veterinarians. Splenic biopsies were formalin-fixed and paraffin-embedded as previously described $[45,46]$. Splenic and nodular mononuclear cells were obtained by mechanical disruption in complete medium (RMPI 1640-glutamax medium supplemented with $1 \mathrm{mM}$ sodium pyruvate, $100 \mu \mathrm{g} / \mathrm{mL}$ streptomycin, $100 \mathrm{UI} / \mathrm{mL}$ penicillin, $10 \mathrm{mM}$ HEPES, $2 \mathrm{mM}$ non-essential amino acids and 10\% heat-inactivated FCS, all from Invitrogen, Life Technologies SAS, Saint Aubin, France), filtered through a 70- $\mu \mathrm{m}$-pore-size cell strainer and further purified by Ficoll gradient centrifugation. Cells were kept frozen in $90 \% \mathrm{FCS} / 10 \%$ DMSO in liquid nitrogen until use.

\subsection{Quantification of Plasma Cytokines, Immunoglobulins and Antigen-Specific Antibodies}

Serum CXCL13 was detected using Quantikine ${ }^{\circledR}$ ELISA kits (Bio-Techne, Lille, France) with sensitivity limit of $3.97 \mathrm{pg} / \mathrm{mL}$. Serum IFN $\alpha 2$ was detected using the Cynomolgus/Rhesus IFN $\alpha$ ELISA kit from PBL Assay Science (Bio-Techne) with a sensitivity limit of $25 \mathrm{pg} / \mathrm{mL}$. Serum BAFF and CXCL10 were detected using a magnetic Luminex Kit (Bio-Techne) with sensitivity limits of $1.01 \mathrm{pg} / \mathrm{mL}$ and $1.18 \mathrm{pg} / \mathrm{mL}$, respectively. Data were acquired using a Bioplex-200 and analyzed with the Bioplex Manager Software (Bio-Rad Laboratories, Redmond, WA, USA). Anti-SIV Abs (IgM plus IgG) were detected in plasma using Genscreen HIV1/2 ELISA kit, version 2 (Bio-Rad Laboratories, Redmond, WA, USA). Total IgM and IgG were quantified in serum by ELISA as previously described [45]. Homemade ELISA was used to quantify serum TT-specific IgM or IgG as previously reported [17]. For each macaque, plasma/serum samples, collected before and at different time points after infection or vaccination, were tested simultaneously and run in duplicates. Results are expressed as mean OD value (SIV- and TT-specific Abs) or as mean concentration (cytokines and total IgM/G).

\subsection{Flow Cytometry Analyses}

Panels of Abs used for multi-parameter FCM are shown in Tables S2 and S3. Optimized concentrations were predetermined for each $\mathrm{Ab}$. For the detection of transcription factors (Bcl-6, Ki67), CD1c, CXCR3, surface receptors of BAFF (BAFF-R, TACI) and for intracellular detection of IFN $\gamma$, relevant $\mathrm{Ab}$ pairs with isotype controls were used and highlighted in tables in grey. After rapid thawing at $37^{\circ} \mathrm{C}$ and two washes in complete medium, cells were surface or intracellularly stained as previously described (17). For surface staining: 1 to $2 \times 10^{6}$ cells in staining buffer (PBS $1 \mathrm{X}$ plus $0.5 \%$ BSA and $2 \mathrm{mM}$ EDTA) were incubated with Live/Dead fixable blue stain (Invitrogen, Life Technologies SAS, Saint-Aubin, France) for $30 \mathrm{~min}$ at $4{ }^{\circ} \mathrm{C}$ before addition of $5 \%$ (vol/vol) heat-inactivated human $\mathrm{AB}$ serum for an extra 15 min at $4{ }^{\circ} \mathrm{C}$. After washing, cells were labeled with appropriate Abs diluted 
in staining buffer for $30 \mathrm{~min}$ at $4{ }^{\circ} \mathrm{C}$, then washed and fixed with $0.5 \%$ paraformaldehyde (PFA). For the detection of transcription factors, cells were first surface stained as above, and then fixed and permeabilized with the FoxP3/Transcription Factor staining buffer set (eBiosciences ${ }^{\mathrm{TM}}$, Paris, France) before intracellular staining with appropriate monoclonal Abs for $45 \mathrm{~min}$ at $4{ }^{\circ} \mathrm{C}$. Cells were washed twice and fixed in $0.5 \%$ PFA. For the detection of intracellular cytokines, cells $\left(2 \times 10^{6} / \mathrm{mL}\right)$ were stimulated for $5 \mathrm{hrs}$ at $37^{\circ} \mathrm{C}$ in $5 \% \mathrm{CO}_{2}$ with PMA $(50 \mathrm{ng} / \mathrm{mL}$ ) and ionomycin $(1 \mu \mathrm{g} / \mathrm{mL})$ in the presence of Brefeldin A (BFA, $10 \mu \mathrm{g} / \mathrm{mL}$ ) during the last $4 \mathrm{~h}$ before staining. After surface staining, cells were fixed with $2 \%$ PFA and treated with the BD cytofix/cytoperm kit before intracellular staining with anti-cytokine Abs. Events were acquired on a BD LSRII and data were analyzed using the Kaluza ${ }^{\circledR}$ Flow Analysis Software (Beckman Coulter, Inc., Villepinte, France). Sphero ${ }^{\mathrm{TM}}$ Rainbow calibration particles (BD Biosciences, Rungis, France) were used for daily calibration of the flow cytometer. Unstained cells and single-color beads were used for calculating the compensation matrix.

\subsection{Immunohistochemistry and Digital Image Analysis}

Sections ( $4 \mu \mathrm{m}$-thick) were cut from formalin-fixed paraffin-embedded spleen blocks. Sections were subject to dewaxing, Ag retrieval, saturation and staining with various monoclonal and polyclonal Abs (Table S4) on a Leica-Bond III/Max autostainer platform (Leica Biosystems Nanterre, France). Detection of primary Ab binding was performed with bond compact polymer Refine detection (DAB, brown), containing substrate chromogen and hematoxylin counterstain.

Images of full section were generated on a Lamina Multilabel Slide Scanner (PerkinElmer, Gif s/Yvette, France), using the brightfield scan mode. Digital images were opened in Pannoramic Viewer software (v1.11.4, 3DHistech, Budapest, Hungary), and areas of interest were manually annotated using the drawing tools. For each section, all (or at least 10) random areas were extracted from the main scan for quantitative analysis. The software automatically calculated the sizes of the whole tissue and of the selected areas (in $\mu \mathrm{m}^{2}$ ). Quantification of positively labeled cells was performed with computer assisted image analysis using Inform (v2.3, 3DHistech, Budapest, Hungary) or Photoshop CS6 (Adobe Systems Inc., San Jose, CA) software by two independent investigators. Mean values of positive cells per area or per $\mathrm{mm}^{2}$ of tissue were calculated for each section and each macaque.

\subsection{Statistical Analysis}

All data were graphed and analyzed using Graphpad Prism (GraphPad Software, San Diego, CA, USA). Bar graphs represent Mean and SD. For pairwise comparisons, data were analyzed using Mann-Whitney U-test (unpaired, 2-tailed). One and 2-way ANOVA was used for multiple comparisons. Correlation coefficients were calculated using the Spearman rank test. Statistical significance is denoted on each figure.

\section{Results}

\subsection{Humoral Response upon SIV-Infection or TT-Vaccination}

Ten macaques were intravenously inoculated with 5000AID50 SIVmac251 and followed for one month (acute phase of infection) before necropsy $\left(G^{2}\right.$ roup SIV ${ }^{+}$). As previously reported, the kinetics of plasma viral load and CD4 T-cell counts in blood evidenced the viral infection and a comparable course of the disease in these macaques [17]. Titers of SIVspecific Abs progressively increased from day 14 post-infection (pi) but not yet reached a plateau value between days 21 and 28 pi (Figure 1A). At day 28 pi, we found no correlation between levels of SIV-specific Abs and either plasma viral loads or blood CD4 T-cell counts (data not shown). Compared to baseline values, total IgM (Figure 1B) and IgG (Figure 1C) titers did not significantly change during the acute phase of infection, suggesting a minor contribution of free SIV-specific Abs to total circulating Ig at that time. 

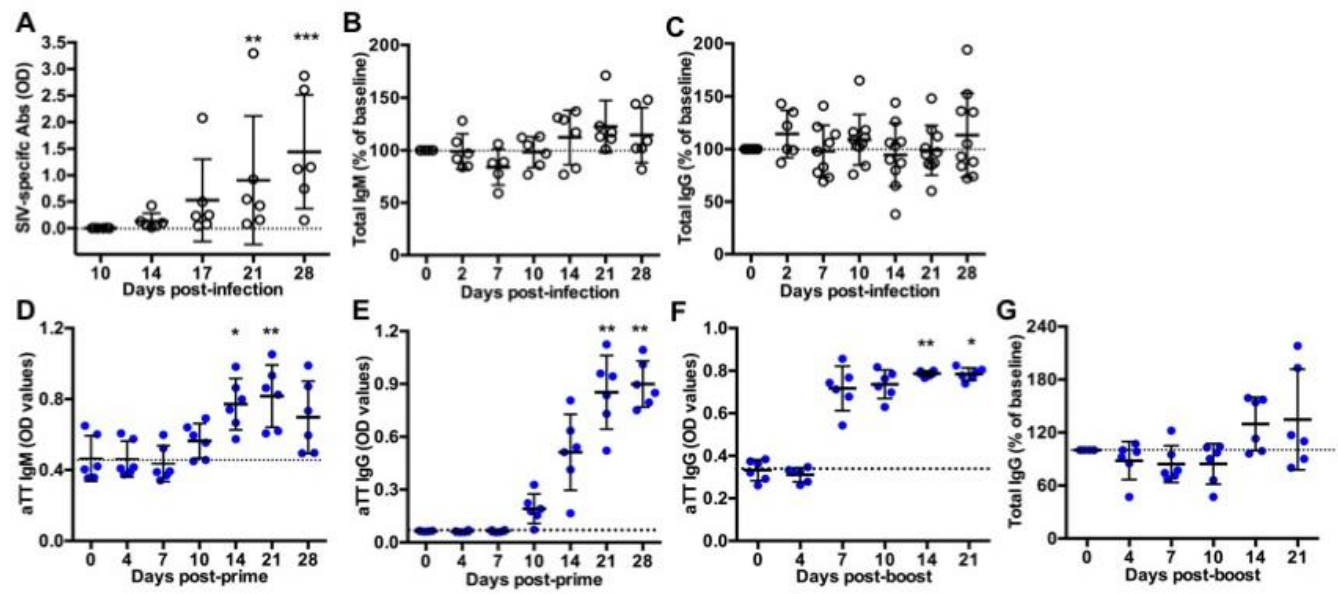

Figure 1. Titers of circulating antibodies in SIV-infected and TT-vaccinated macaques. ELISA was used to quantify (A) SIV-specific antibodies, (B) total IgM or (C) total IgG in plasma from SIV-infected macaques; (D) TT-specific IgM and (E) TT-specific IgG in serum from vaccinated macaques after the prime or (F) after the boost; and (G) total IgG in serum from TT-boosted animals. Values of specific TT- and SIV-specific Abs are given in OD values (A,D-F). Changes in total IgM and IgG concentration were expressed as the percentage of baseline value for each animal (B,C,G). A dotted line indicates the baseline value at D0. Each dot represents one macaque from Group SIV (open circle) or TT (blue circle). Bars represent Mean \pm SD. Statistical comparison between values at D0 and at every time point was performed using Friedman test with Dunn's multiple comparisons test. ${ }^{*} p<0.05,{ }^{* *} p<0.01$ and ${ }^{* * *} p<0.001$.

Six macaques received a first IM injection of TT vaccine and a booster dose 40 days later (Group TT). This time point was thereafter considered as day 0 (D0) post-boost (pb). Titers of TT-specific IgM (Figure 1D) and IgG (Figure 1E) increased from day 10 post-prime. IgM titers peaked at day 21 post-prime with a slight non-significant decrease at day 28 (Figure 1D), whereas anti-TT IgG titers reached a plateau value from day 21 post-prime (Figure 1E). After the boost, levels of anti-TT IgG rapidly reached a plateau value from day $7 \mathrm{pb}$ (Figure 1F), possibly due to a substantial differentiation of memory B-cells and PBs into plasma cells. Median value of total IgG titers increased by $33.5 \%$ at day $14 \mathrm{pb}$ and by $13.5 \%$ at day $21 \mathrm{pb}$ but these differences did not reach statistical significance (Figure 1G).

\subsection{Systemic Inflammation upon SIV-Infection or TT-Vaccination}

Inflammation at the site of virus infection or immunization is key for developing innate and adaptive immunity. HIV/SIV infection induces a storm of inflammatory cytokines during the acute phase with type I IFN contributing to the control of viremia, as shown in humanized mice [47]. In TT vaccine, Tetanus Toxoid is adsorbed on aluminum phosphate salts, forming a combination of Ag-adjuvant mandatory for initiating TT-specific Ab responses through local inflammation [48]. After IM vaccination of mice with TT, this local inflammation relies on cytokine/chemokine release, early recruitment of neutrophils followed by a more sustained recruitment of macrophages and dendritic cells (DCs). Recruitment of these cells is more pronounced after a booster injection [49]. Accordingly, we measured levels of blood inflammatory cytokines in both groups (Figure 2A). Consistent with our previous data [17], levels of IFN $\alpha 2$, CXCL10, BAFF and CXCL13 were elevated during the acute phase of SIV infection, with a peak at days 7 pi (IFN $\alpha 2$, CXCL10), 10pi (BAFF) or 14pi (CXCL13), respectively. In contrast to IFN $\alpha 2$ levels which returned to baseline value from day 14 pi, levels of CXCL10, BAFF and CXCL13 were still elevated at days 21 and 28 pi compared to baseline values. In TT-vaccinated macaques, serum IFN $\alpha 2$, CXCL10 and BAFF levels remained roughly unchanged over time after the prime (data not shown) and the boost (Figure 2A). After the booster dose, the highest CXCL13 value was observed between days 4 and 10 in most macaques (Figure S1) and the average value of the 
group increased by $53 \%$ at day $4 \mathrm{pb}$ compared to pre-boost $(34.6 \mathrm{pg} / \mathrm{mL}$ vs. $22.6 \mathrm{pg} / \mathrm{mL})$ (Figure 2A and Figure S1). A modest increase was also observed at days $7(22 \%)$ and $10(20 \%)$ post-prime compared to pre-vaccination value (Figure S1). Collectively, this indicates that substantial titers of TT-specific IgG developed despite a limited inflammation at systemic level compared to SIV infection.
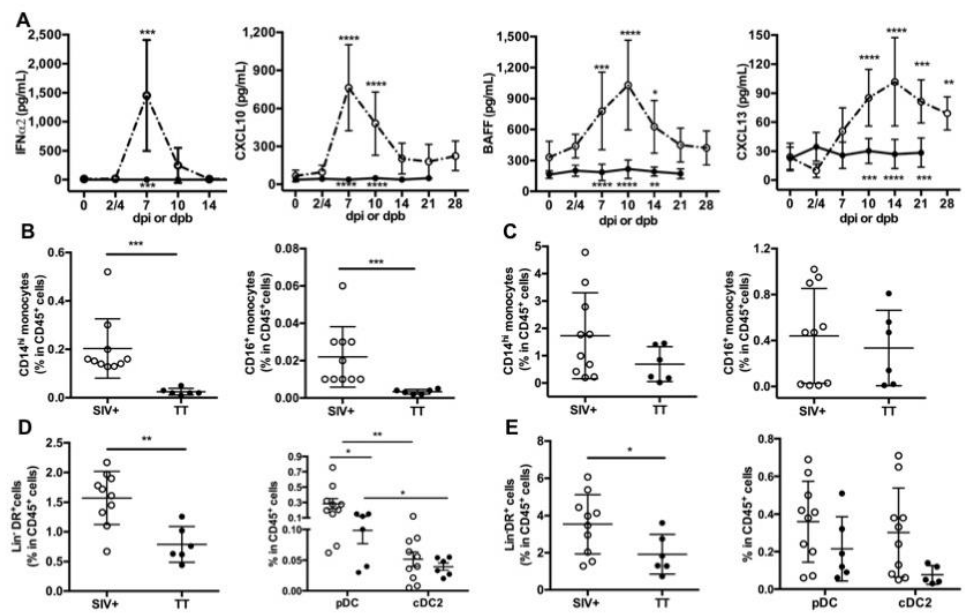

Figure 2. Circulating inflammatory cytokines and proportions of antigen-presenting cells in lymphoid organs. (A) ELISA was used to quantify serum levels of IFN $\alpha 2$ and CXCL13, whereas serum CXCL10 and BAFF were detected by using a magnetic Luminex kit. Samples were tested prior to infection or to booster injection (baseline value, D0) and at different time points post-infection (dpi) or post-boost $(\mathrm{dpb})$. Mean $\pm \mathrm{SD}$ values for group of SIV-infected macaques (open circle, dotted line) or TT-vaccinated macaques (black circle; plain line) at the various time points are given. Statistical comparison between values at D0 and at every time point post-infection (Group SIV ${ }^{+}$) or post-boost (Group TT) was carried using a Friedman test with Dunn's multiple comparisons test. Statistically significant values are indicated above dotted lines. Comparison between values of each group at every time point was carried using 2-way ANOVA with Bonferroni's multiple comparisons test. $p$ values are indicated below the plain lines: ${ }^{* *} p<0.01,{ }^{* * *} p<0.001$, and ${ }^{* * * *} p<0.0001$. Proportions of CD14 ${ }^{\text {hi }}$ and CD16 ${ }^{+}$ monocytes in $\mathrm{CD}_{4} 5^{+}$cells from Group SIV ${ }^{+}$and Group TT were compared in LNs (B) and spleen (C). Proportions of $\mathrm{Lin}^{-} \mathrm{DR}^{+}$cells in $\mathrm{CD}^{+} 5^{+}$cells from Group $\mathrm{SIV}^{+}$and Group TT are shown in LNs (D, left panel) and spleen (E, left panel). Proportions of pDC and $\mathrm{CDC} 2$ in $\mathrm{CD} 45^{+}$cells are given in LN (D, right panel) and spleen (E, right panel). For (B-E) each dot represents one macaque from Group SIV ${ }^{+}$(open circle) or TT (black circle). Bars represent Mean \pm SD. Statistical comparison between groups was performed using Mann Whitney non-parametric test. Statistically significant values are indicated ${ }^{*} p<0.05,{ }^{* *} p<0.01$ and ${ }^{* * *} p<0.001$.

Since recruitment of APCs is influenced by inflammation at the site of immunization or infection, we sought to determine whether monocytes and DCs were differently represented in inguinal LNs and spleen from Groups SIV ${ }^{+}$and TT at necropsy (day 28 pi and day $21 \mathrm{pb}$ ). In both lymphoid organs, CD14hi monocytes outnumbered CD16 ${ }^{+}$monocytes. Frequencies of $\mathrm{CD} 14^{\mathrm{hi}}$ and $\mathrm{CD} 16^{+}$monocytes among $\mathrm{CD} 45^{+}$cells were significantly much higher in $\mathrm{LNs}$ from SIV-infected macaques than from TT-vaccinated macaques (Figure 2B). Whereas a trend to higher proportions of every monocyte subset was also observed in spleen from SIVinfected macaques, differences did not reach statistical significance (Figure 2C). Compared to TT-vaccinated macaques, total DCs ( $\mathrm{Lin}^{-} \mathrm{DR}^{+}$cells) were more frequent among $\mathrm{CD} 45^{+}$ cells in LNs (Figure 2D, left panel) and spleen (Figure 2E, left panel) from SIV-infected macaques, suggesting a more potent recruitment of APCs in this group. Nodular pDC were more frequent than $\mathrm{CD} 1 \mathrm{c}^{+} \mathrm{DC}(\mathrm{cDC} 2)$ in both settings, with significantly higher frequencies of $\mathrm{pDC}$ in group $\mathrm{SIV}^{+}$than in group TT (Figure 2D, right panel). Consistent with monocytes releasing CXCL13 upon activation [50], serum CXCL13 titers correlated with the frequencies of CD14 ${ }^{\text {hi }}$ and $\mathrm{CD} 16^{+}$monocytes in LNs but not in spleen (Table 1). 
Similarly, titers of IFN $\alpha$, CXCL10 and BAFF correlated with frequencies of monocytes and total DCs in LNs, with pDC frequencies correlating with CXCL10 and BAFF titers only (Table 1). In spleen, such a correlation was found between CXCL10 titers and frequencies of CD14 $4^{\text {hi }}$ and total DCs, and between BAFF titers and frequencies of total DCs and cDC2. Compared to TT vaccination, SIV infection is thus associated with a more intense APC mobilization and cytokine release. Despite lower inflammation, levels of TT-specific Abs raised rapidly from day 10 post-prime and from day $7 \mathrm{pb}$. Circulating SIV-specific Abs were only detectable from day 14 pi but their measurement during the two first weeks of infection is likely biased by their capture by high amounts of viral Ags resulting from increased virus production during this period. Consistently, SHIV-specific Abs are more rapidly detected in vaccination setting than after infection [13,14].

Table 1. Monocytes and DC: Correlation with inflammation.

\begin{tabular}{|c|c|c|c|c|c|}
\hline \multirow[b]{3}{*}{ Cytokine $^{b}$} & \multirow[b]{3}{*}{ Cell Subset $^{c}$} & \multirow{2}{*}{\multicolumn{2}{|c|}{$\begin{array}{c}\text { Lymph Node } \\
\text { Spearman Rank Test }^{\mathrm{a}}\end{array}$}} & \multirow{2}{*}{\multicolumn{2}{|c|}{$\frac{\text { Spleen }}{\text { Spearman Rank Test }^{\mathrm{a}}}$}} \\
\hline & & & & & \\
\hline & & $p$ Values & rho & $p$ Values & rho \\
\hline & $\begin{array}{c}\mathrm{CD} 14^{\mathrm{hi}} \\
\text { monocytes }\end{array}$ & * & 0.5801 & $n s$ & \\
\hline & $\begin{array}{l}\mathrm{CD}^{\mathrm{C}} 6^{+} \\
\text {monocytes }\end{array}$ & $* *$ & 0.640 & ns & \\
\hline \multirow[t]{5}{*}{ CXCL13 } & Total DC $^{\mathrm{d}}$ & $n s$ & & $n s$ & \\
\hline & cDC2 & ns & & 0.064 & 0.492 \\
\hline & $\mathrm{pDC}$ & $n s$ & & ns & \\
\hline & $\begin{array}{l}\mathrm{CD} 14^{\mathrm{hi}} \\
\text { monocytes }\end{array}$ & * & 0.611 & ns & \\
\hline & $\begin{array}{l}\mathrm{CD}^{\mathrm{C}} 6^{+} \\
\text {monocytes }\end{array}$ & * & 0.571 & ns & \\
\hline \multirow[t]{5}{*}{ IFN $\alpha$} & Total DC & $*$ & 0.567 & ns & \\
\hline & cDC2 & ns & & ns & \\
\hline & $\mathrm{pDC}$ & $n s$ & & ns & \\
\hline & $\begin{array}{l}\mathrm{CD} 14^{\mathrm{hi}} \\
\text { monocytes }\end{array}$ & ** & 0.737 & * & 0.555 \\
\hline & $\begin{array}{l}\mathrm{CD}^{\mathrm{C}} 6^{+} \\
\text {monocytes }\end{array}$ & $* * *$ & 0.767 & ns & \\
\hline \multirow[t]{5}{*}{ CXCL10 } & Total DC & * & 0.603 & * & 0.632 \\
\hline & cDC2 & ns & & ns & \\
\hline & $\mathrm{pDC}$ & $*$ & 0.616 & ns & \\
\hline & $\begin{array}{l}\mathrm{CD} 14^{\mathrm{hi}} \\
\text { monocytes }\end{array}$ & $* *$ & 0.748 & 0.056 & 0.491 \\
\hline & $\begin{array}{l}\mathrm{CD}^{\mathrm{C}} 6^{+} \\
\text {monocytes }\end{array}$ & $* * *$ & 0.811 & ns & \\
\hline \multirow[t]{3}{*}{ BAFF } & Total DC & * & 0.539 & * & 0.569 \\
\hline & cDC2 & ns & & $* *$ & \\
\hline & $\mathrm{pDC}$ & $* *$ & 0.677 & ns & 0.690 \\
\hline
\end{tabular}

a Spearman rank test was used for testing correlation. Sixteen animals were considered for all analyses. Statistically significant values are indicated: ${ }^{*} p<0.05,{ }^{* *} p<0.01$ and ${ }^{* * *} p<0.001 ; n s$, not significant; ${ }^{\mathrm{b}}$ For CXCL13, titers at day $4 \mathrm{pb}$ for the TT group and at day 14 pi for the SIV ${ }^{+}$group were used. Titers at day 7 (IFN $\left.\alpha\right)$ and day 10 (CXCL10, BAFF) pi or pb were used. ${ }^{c}$ Cell subsets as percent of CD $45^{+}$cells. ${ }^{d}$ Total DC subset corresponds to Lin $^{-} \mathrm{DR}^{+}$cells.

\subsection{Differences in Nodular B-Cells and $T_{F H}$ Associated with Responses to TT or SIV}

We next compared the B-cell compartment in inguinal LNs from Groups SIV (day 28 pi) and TT (day $21 \mathrm{pb}$ ). Using polychromatic staining (Table S2, Panel 2) and the gating strategy depicted in Figure S2, we identified various B-cell subsets. Proportions of total B-cells $\left(\mathrm{CD} 19^{+} \mathrm{CD} 20^{+}\right)$in $\mathrm{CD} 45^{+}$cells were comparable in the Group TT $(33.5 \% \pm 4.7 \%)$ and in a group of healthy "control" macaques $(36 \% \pm 8.5 \%, n=3)$ (data not shown). Compared to the Group TT, a trend to higher proportions of total B-cells (1.3-fold) was observed in the Group SIV $^{+}$(Figure 3A). When all macaques were considered, frequency of total B-cells 
inversely correlated with that of $\mathrm{CD}^{+}$T-cells $(r=-0.979, p<0.0001)$ but not with that of CD4 T-cells $(r=-0.286, p=0.301)$ in $\mathrm{CD}^{+} 5^{+}$cells (data not shown).
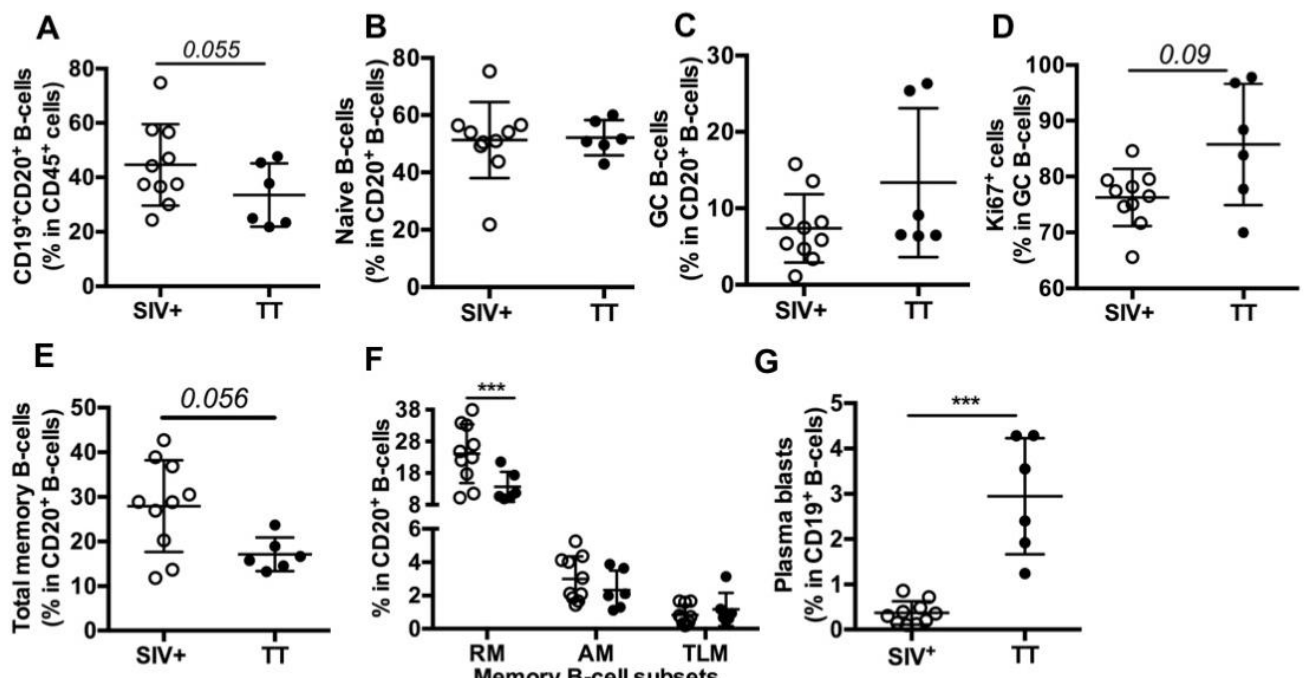

$\mathbf{F}$

G
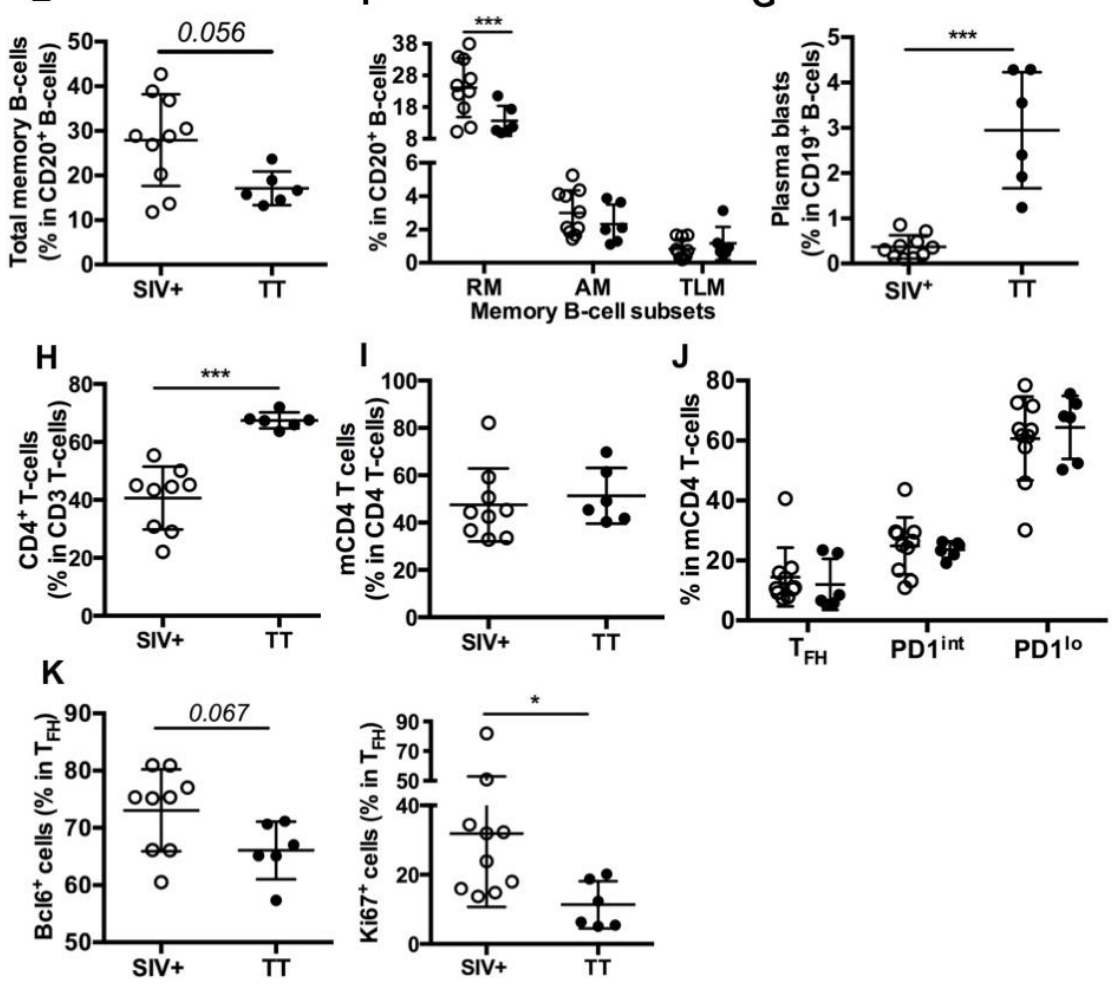

Figure 3. B- and T-cell subsets in inguinal LNs from SIV-infected and TT-vaccinated macaques. Cell proportions were determined by FCM for each macaque. Shown are proportions of $(\mathrm{A}) \mathrm{CD} 19^{+} \mathrm{CD} 20^{+} \mathrm{B}$-cells (thereafter referred to as $\mathrm{CD} 20^{+}$ B-cells) in nodular CD45 $5^{+}$cells; (B,C) naïve and GC B-cells in CD20 ${ }^{+}$B-cells; (D) Ki67 cells in GC B-cells; (E,F) Total memory, RM, AM and TLM B-cells in CD20 B-cells; (G) plasma blasts in CD19+ B-cells; (H) CD4 ${ }^{+}$T-cells in CD3 ${ }^{+}$T-cells; (I) memory CD4 T-cells (mCD4 T-cells) in CD4 ${ }^{+}$T-cells; (J) $\mathrm{T}_{\mathrm{FH}}$, PD1 $1^{\text {int }}$ and PD1 $1^{\text {lo }}$ subsets in mCD4 T-cells and (K) Bcl- $6^{+}$and Ki67 ${ }^{+}$ cells in $\mathrm{T}_{\mathrm{FH}}$ are shown. Each dot represents one macaque from the $\mathrm{SIV}^{+}$(open circle) or TT (black circle) group. Bars represent Mean \pm SD. For all panels except $(\mathbf{F})$ and $(\mathbf{J})$, statistical comparison between groups was performed using the Mann Whitney non-parametric test. For $(\mathbf{F})$ and (J) panels, statistical comparison was performed using 2-way ANOVA with Bonferroni's multiple comparisons test. Statistically significant values are indicated: ${ }^{*} p<0.05$ and ${ }^{* * *} p<0.001$.

Similar proportions of naïve B-cells (Figure $3 \mathrm{~B}$ ) were found in both groups but proportions of total GC B-cells (13.4\% vs. 7.4\%, Figure 3C) and of proliferating GC B-cells (86\% vs. $76 \%, p=0.09$, Figure 3D) tended to be higher in the Group TT than in the Group SIV ${ }^{+}$. Lower proportions of total memory (Figure 3E) and RM B-cells (Figure 3F) were found in the Group TT whereas percentages of AM and TLM B-cells were similar in both groups (Figure 3F), with total CD21 ${ }^{\text {lo }}$ memory B-cells representing $3.8 \pm 0.52 \%$ and $3.5 \pm 0.81 \%$ of B-cells in the Groups SIV ${ }^{+}$and TT, respectively (data not shown). In contrast to RM B-cells, plasma blasts/cells $\left(\mathrm{CD} 19^{+} \mathrm{CD} 20^{-}\right)$were more frequent in TT-vaccinated macaques than in SIV-infected ones (Figure 3G). When all macaques were considered, percentages of GC B-cells correlated with those of plasma blasts/cells $(r=0.55, p<0.03)$ but not with 
those of total memory or RM B-cells (not shown). However, percentages of RM and plasma blasts / cells tended to inversely correlate $(r=-0.494, p=0.054)$. We thus infer that higher PB proportions in the LNs of boosted macaques rely on enhanced extrafollicular differentiation of RM B-cells into PBs and on biased generation of PBs over RM B-cells in secondary GC.

Consistent with SIV infection depleting CD4 ${ }^{+}$T-cells, their proportions were lower in SIV-infected macaques than in TT-vaccinated ones (Figure 3H). Based on the expression levels of PD1 and ICOS (Table S2, Panel 3) on mCD4 T-cells, we distinguished three subsets referred to as $\mathrm{T}_{\mathrm{FH}}, \mathrm{PD}^{\text {int }}$ and $\mathrm{PD} 1^{\text {lo }}$ (Figure S3). Despite similar proportions of $\mathrm{mCD} 4$ T-cells (Figure 3I), nodular mCD4 T-cells preferentially exhibited a PD1 ${ }^{\text {lo }}$ phenotype in both groups, with only $14.5 \%$ and $12 \%$ being $\mathrm{T}_{\mathrm{FH}}$ in the Groups $\mathrm{SIV}^{+}$and TT, respectively. No significant difference between groups was observed for each mCD4 T-cell subset (Figure 3J). Frequencies of GC B-cells did not correlate with those of $\mathrm{T}_{\mathrm{FH}}$ in $\mathrm{mCD} 4$ T-cells but correlated with frequencies of $\mathrm{T}_{\mathrm{FH}}$ in CD4 T-cells $(r=0.609, p<0.02)$ (not shown). Higher frequencies of Bcl- $6^{+}$and $\mathrm{Ki}_{67}^{+}$cells were found in $\mathrm{T}_{\mathrm{FH}}$ from the Group $\mathrm{SIV}^{+}$compared to the Group TT (Figure $3 \mathrm{~K}$ ), possibly indicating less active $\mathrm{T}_{\mathrm{FH}}$ in this later group. With less APCs being present in LNs from boosted macaques and lower inflammation (Figure 2D), polarization of CD4 T-cells into $\mathrm{T}_{\mathrm{FH}}$ is likely less strong and enduring in vaccinated macaques than in SIV-infected ones. Indeed, $\mathrm{T}_{\mathrm{FH}}$ themselves constitute a persistent source of viral Ags in GC of SIV-infected macaques, whereas TT concentrations progressively wane.

\subsection{Differences in Splenic B-Cells Associated with Responses to TT or SIV}

As evidenced on spleen section stained with CD20 Ab, surface of B-cell areas was comparable between the Groups SIV ${ }^{+}$and TT $(19.2 \pm 1.6 \%$ and $17.4 \pm 2.5 \%$ of the total tissue, respectively) (not shown). However, $\mathrm{CD} 19^{+} \mathrm{CD} 20^{+}$B-cells were $38 \%$ more frequent among CD45 ${ }^{+}$cells in the Group TT than in the Group SIV ${ }^{+}$(Figure 4A), with a 1.75-fold more naïve B-cells (Figure 4B) and obvious lower proportions of total (Figure 4C) and AM memory B-cells (Figure 4D).

By using IHC approach and Ki67 staining, we found that frequencies of active follicles (follicles with GC) were not different between both groups (54.9 $\pm 4.8 \%$ in the Group $\mathrm{SIV}^{+}$and $46.3 \pm 4.6 \%$ in the Group TT), but the area occupied by GC within follicle was $30 \%$ lower in the Group TT than in the Group SIV ${ }^{+}$(not shown). FCM analysis showed that proportions of GC B-cells in total B-cells were 63\% lower in the Group TT than in the Group SIV ${ }^{+}$(Figure 4E) but exhibited higher expression of Bcl-6 (gMFI) (Figure 4F) and contained a higher percentage of proliferating (Ki67 ${ }^{+}$cells) B-cells (Figure $\left.4 \mathrm{G}\right)$. No difference in the intensity of Ki67 expression (average gMFI was $10.7 \pm 1.1$ for the Group $\mathrm{SIV}^{+}$vs. $13.5 \pm 1.4$ for the Group TT) was concurrently observed (data not shown). When all macaques were considered, frequency of GC B-cells inversely correlated with that of naïve B cells $(r=-0.732, p<0.002)$ (Figure $4 \mathrm{H})$. A three-fold increase in the number of apoptotic cells (aCas- $3^{+}$cells) was detected in GC from the Group SIV ${ }^{+}$compared to the Group TT (Figure 4I), with most of them being CD3-negative cells (data not shown). Thus, one third of GC B-cells failed to develop into effectors in the Group $\mathrm{SIV}^{+}$. Numbers of aCas $-3^{+}$cells positively correlated with frequencies of total GC B-cells $(r=0.634, p<0.01)$ but inversely with those of proliferating GC B-cells $(r=-0.622, p<0.02)$ (not shown).

Plasma blasts/cells were significantly less frequent in the Group TT than in the Group $\mathrm{SIV}^{+}$(Figure 4J). When PBs were quantified in GC by using IHC and IRF4 staining, we consistently found less total PBs per GC in TT-vaccinated macaques than in SIV-infected ones (Figure 4K-M). This difference essentially relied on lower numbers of IgG PBs in the TT group (Figure $4 \mathrm{~N}$ ). Accordingly, the average value of $\operatorname{IgG}$ to $\operatorname{IgM}$ ratio was 5.4 and 1.4 in the Group SIV ${ }^{+}$and Group TT, respectively. Compared to response to SIV Ags, response to TT is thus associated with less PBs and AM B-cells in spleen. Frequency of GC B-cells correlated with that of PBs $(r=0.634, p<0.03)$ (not shown). In contrast to TT antigen transiently exposing a define pool of B-cell epitopes, SIV likely exposes a more diversified 
pool of antigens that persists and dynamically evolves during the first month of infection.

This might contribute to a broader stimulation of B-cells entering GC and generating PBs.

A

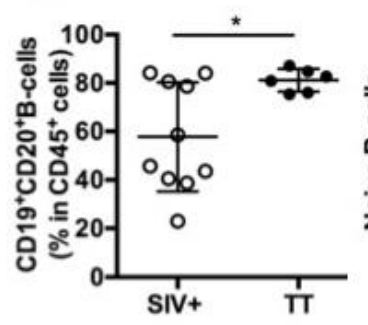

E

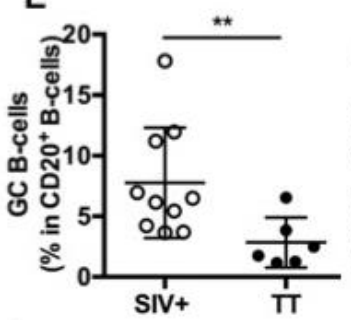

I

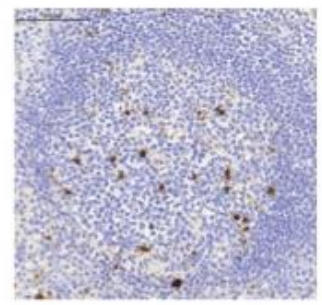

L

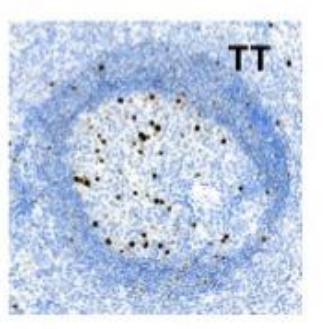

B

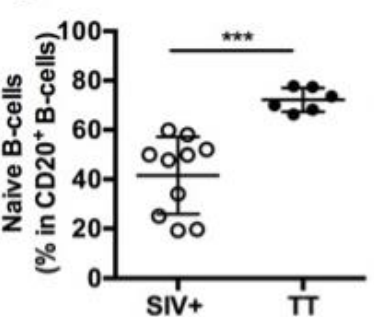

F
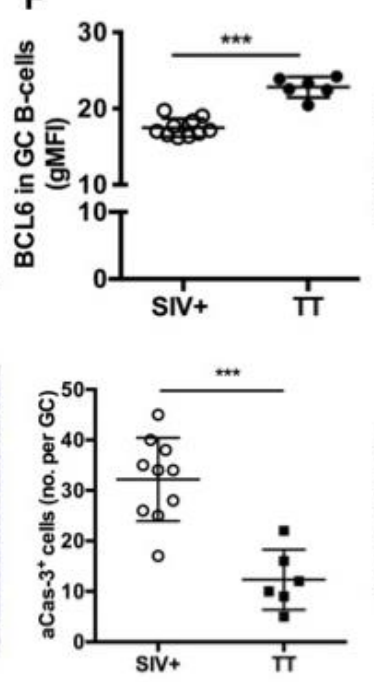

M

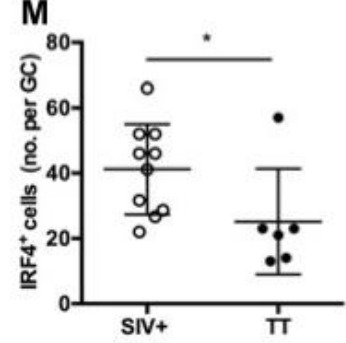

C

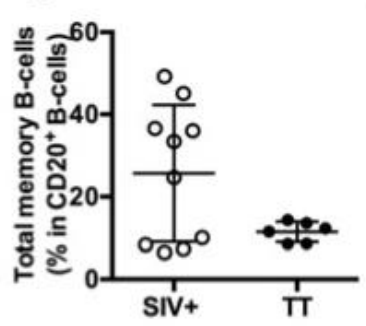

G

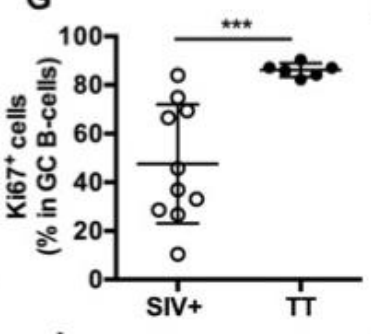

J

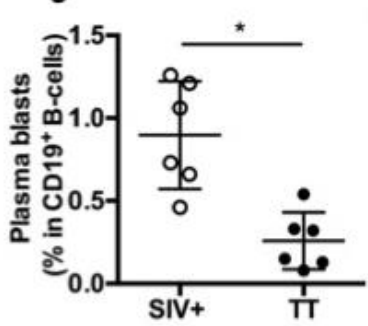

N

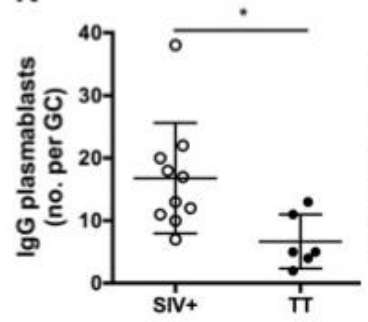

D

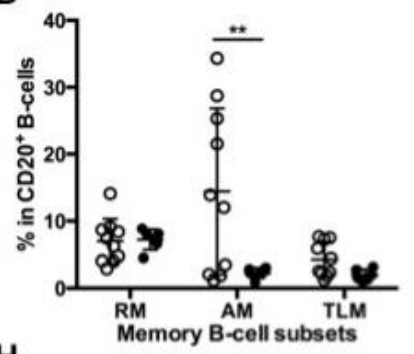

H

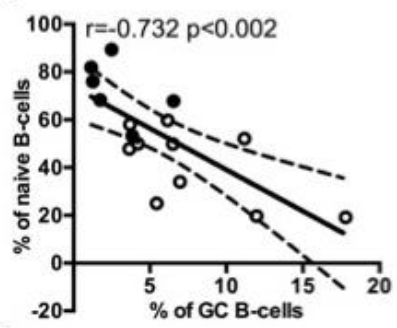

K
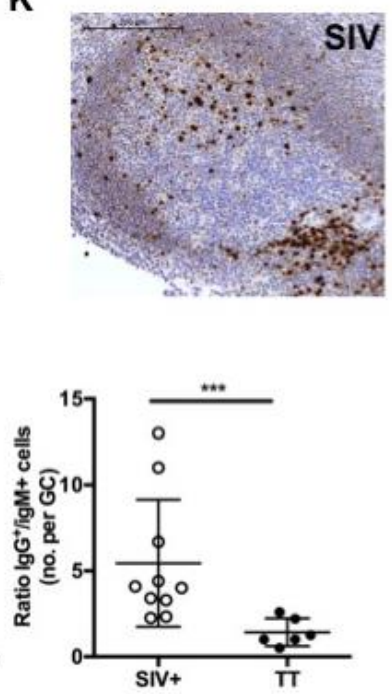

Figure 4. Splenic B-cell subsets in SIV-infected and TT-vaccinated macaques. (A) Proportions of CD19 ${ }^{+} \mathrm{CD} 20^{+} \mathrm{B}-\mathrm{cells}$ in CD45 ${ }^{+}$cells as well as proportions of (B) naïve, (C) Total memory B-cells; (D) RM, AM and TLM B-cells; and (E) GC B-cells in $\mathrm{CD} 20^{+}$B-cells were determined by multi-parameter FCM for each macaque. (F) Intensity of Bcl-6 expression (gMFI) and (G) proportions of $\mathrm{Ki}^{+} 7^{+}$cells in GC B-cells are shown. (H) Graph represents the correlation between the percentages of GC and naïve B-cells. Spearman rank test was used for statistical analyses. rho and $p$ values are given. (I) Representative staining with active-caspase-3 (aCas-3) Ab on section of one macaque from Group TT. Scale Bar $=200 \mu \mathrm{m}$ (left panel), graph represents the Mean number of aCas- $3^{+}$cells per GC for each macaque (right panel). (J) Proportions of plasma blasts (PBs) in $\mathrm{CD} 19^{+}$B-cells are shown. $(\mathbf{K}, \mathrm{L})$ Representative IRF4 staining on sections of one representative macaque from Groups (K) $\mathrm{SIV}^{+}$and (L) TT. Scale Bar $=200 \mu \mathrm{m}$. (M) Graph represents the Mean number of IRF4 $4^{+}$cells per GC for each macaque. (N) Graph represents the Mean number of $\mathrm{IgG}^{+}$cells per GC for each macaque (left panel). Ratio between numbers of IgG and IgM PBs per GC was plotted for each macaque (right panel). In all panels, each dot represents one macaque from Groups SIV ${ }^{+}$(open circle) or TT (black circle). For all panels except $(\mathbf{H})$, bars represent Mean \pm SD. For all panels except (D) and (H), statistical comparison between groups was performed using Mann Whitney non-parametric test. For panel (D), statistical comparison between groups was performed using 2-way ANOVA with Bonferroni's multiple comparisons test. Significant statistical values are indicated: ${ }^{*} p<0.05,{ }^{* *} p<0.01$ and ${ }^{* * *} p<0.001$. 


\subsection{Major Differences in Splenic $T_{F H}$ and Other $m C D 4$ T-Cell Subsets between the Two Groups}

As previously observed in $\mathrm{LNs}$ (Figure $3 \mathrm{H}$ ), percentages of $\mathrm{CD}^{+}{ }^{+} \mathrm{T}$-cells among $\mathrm{T}$ cells were reduced in spleen from the Group SIV ${ }^{+}$compared to the Group TT (Figure 5A), with similar proportions of mCD4 T-cells (Figure 5B). Among mCD4 T-cells, SIV infection and TT vaccination were associated with a different balance between $\mathrm{T}_{\mathrm{FH}}$ and PD1 ${ }^{\text {lo }}$ cells (Figure 5C). Indeed, proportions of $\mathrm{T}_{\mathrm{FH}}$ were significantly lower in the Group TT compared to the Group $\mathrm{SIV}^{+}$, whereas an opposite trend was observed for the PD1 $1^{\text {lo }}$ subset. However, comparable percentages of $\mathrm{Bcl}-6^{+}$and $\mathrm{Ki} 67^{+}$cells were found among $\mathrm{T}_{\mathrm{FH}}$ in both settings (data not shown). When all macaques were considered, proportions of splenic $\mathrm{T}_{\mathrm{FH}}$ significantly correlated with those of GC B-cells (Figure 5D) and with levels of inflammatory cytokines, in particular CXCL13 which can guide $\mathrm{T}_{\mathrm{FH}}$ recruitment into GC (Table 2).

To further evaluate potential difference in $\mathrm{T}_{\mathrm{FH}}$ polarization between the two groups, we first examined the intracellular expression of IFN $\gamma$ in various $\mathrm{mCD} 4 \mathrm{~T}$-cell subsets (Table S2, panel 4). IFN $\gamma$-expressing cells represented $14 \%$ of $\mathrm{T}_{\mathrm{FH}}$ in SIV-infected macaques but only $3 \%$ in TT-vaccinated macaques. However, higher proportions of IFN $\gamma^{+}$cells were present in PD1 ${ }^{\text {lo }}$ and PD $1^{\text {int }} \mathrm{mCD} 4$ T-cells than in $\mathrm{T}_{\mathrm{FH}}$ in both settings. Indeed, $25 \%$ of PD $1^{\text {lo }}$ and $20 \%$ of PD $1^{\text {int }} \mathrm{mCD} 4$ T-cells were IFN $\gamma^{+}$in SIV-infected macaques, whereas only $7.3 \%$ and $12 \%$ of these subsets were IFN $\gamma^{+}$in the Group TT (Figure 5E). Alternatively, we examined the expression of CXCR3 in $\mathrm{T}_{\mathrm{FH}}$ and other mCD4 T-cells (Table $\mathrm{S} 2$, panel 5). Consistent with data on IFN $\gamma$ expression in $\mathrm{T}_{\mathrm{FH}}, \mathrm{CXCR}^{+} \mathrm{T}_{\mathrm{FH}}\left(\mathrm{T}_{\mathrm{FH} 1}\right.$-like) were significantly more frequent in the Group SIV ${ }^{+}$than in the Group TT (70.5 $\pm 3.6 \%$ vs. $51 \pm 3.5 \%$, respectively) (Figure $5 \mathrm{~F}$ ).

We have recently shown that follicular $\mathrm{CD}^{+}$(fCD8) T-cells infiltrate GC as soon as the acute phase of SIV infection [17]. As expected, TT vaccination was characterized by lower numbers of fCD8 per GC compared to SIV infection (Figure 5G). Similar results were observed when positive cells per $\mathrm{mm}^{2}$ of GC area were considered (not shown). Consistent with a role of monocytes-mediated inflammation in the recruitment of fCD8 T-cells, number of infiltrating macrophages ( $\mathrm{CD}^{+} 8^{+}$cells) in GC, that was significantly higher in the Group $\mathrm{SIV}^{+}$than in the Group TT (Figure 5H), correlated with numbers of fCD8 but also with frequency of $\mathrm{T}_{\mathrm{FH}}$ (Figure 5I). In addition, numbers of fCD8 in GC correlated with CXCL10 and CXCL13 titers (Table 2). Follicular regulatory T-cells $\left(\mathrm{T}_{\mathrm{FR}}, \mathrm{FOXP3}^{+}\right)$were rare in GC in both settings but higher number per GC and B-cell follicle were found in the Group TT (Figure 5J). Accordingly, the ratio between $\mathrm{T}_{\mathrm{FH}}$ and $\mathrm{T}_{\mathrm{FR}}$ was significantly lower in TT-boosted animals compared to the Group $\mathrm{SIV}^{+}(6.1 \pm 1.8 \%$ vs. $22.4 \pm 3 \%)$ (Figure 5K).

Table 2. Correlation between cytokine titers in blood and frequencies of T-cell subsets and monocytes in spleen GC.

\begin{tabular}{cccc}
\hline \multirow{2}{*}{ Subset } & \multirow{2}{*}{ Cytokine $^{\text {a }}$} & \multicolumn{2}{c}{ Spearman Rank Test $^{\text {b }}$} \\
\cline { 3 - 4 } & & $p$ Values & Rho \\
\hline & IFN $\alpha$ & $* *$ & 0.761 \\
$\mathrm{~T}_{\text {FH }}$ & CXCL10 & $* *$ & 0.743 \\
$\%$ in mCD4 T-cells & CXCL13 & $*$ & 0.571 \\
\hline \multirow{2}{*}{ CD68 ${ }^{+}$cells } & IFN $\alpha$ & $* * * *$ & 0.841 \\
no. per GC & CXCL10 & $* * * *$ & 0.853 \\
& CXCL13 & $n s$ & 0.734 \\
\hline & BAFF & ${ }^{* *}$ & 0.854 \\
fCD8 T-cells & IFN $\alpha$ & $* * * *$ & 0.730 \\
no. per GC & CXCL10 & ${ }^{* *}$ & 0.584 \\
\hline
\end{tabular}

a Titers were considered at day $7 \mathrm{pi}$ or $\mathrm{pb}$ for IFN $\alpha$ and at day $10 \mathrm{pi}$ or $\mathrm{pb}$ for BAFF and CXCL10. CXCL13 titers were considered at day $4 \mathrm{pb}$ and day 14 pi for the groups TT and $\mathrm{SIV}^{+}$, respectively; ${ }^{\mathrm{b}}$ Ten SIV-infected macaques and 6 TT-vaccinated macaques were considered for correlation analysis. Statistically significant values are indicated: ${ }^{*} p<0.05,{ }^{* *} p<0.01$ and ${ }^{* * *} p<0.0001 ; n s$, not significant. 

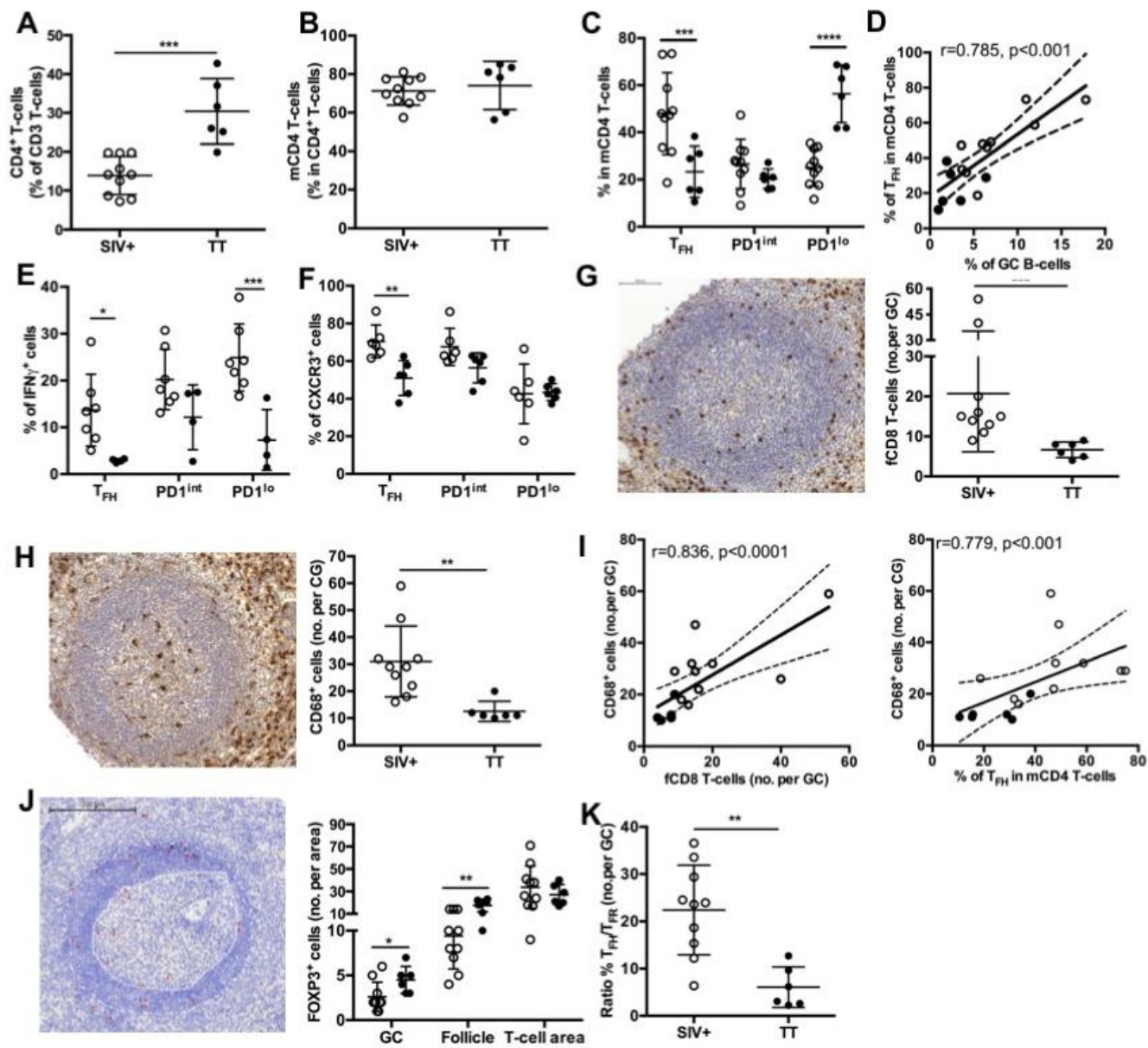

Figure 5. Splenic T-cell subsets in SIV-infected and TT- vaccinated macaques. Proportions of (A) CD4 ${ }^{+}$T-cells in total T-cells and (B) mCD4 T-cells in CD4 ${ }^{+}$T-cells are shown. (C) Proportions of $\mathrm{T}_{\mathrm{FH}}, \mathrm{PD} 1^{\text {int }}$ and PD1 ${ }^{\text {lo }}$ subsets for each macaque are shown. Statistical comparison between groups was performed using 2-way ANOVA with Bonferroni's multiple comparisons test. Statistically significant values are indicated: ${ }^{* * *} p<0.001,{ }^{* * * *} p<0.0001$. (D) Correlation between the percentages of GC B-cells and $\mathrm{T}_{\mathrm{FH}}$ is shown. Spearman rank test was used for statistical analyses. rho and $p$ values are given. (E) Proportions of IFN $\gamma^{+}$cells in every mCD4 T-cells are plotted for each macaque. Seven and four macaques have been tested for the Group $\mathrm{SIV}^{+}$and TT, respectively. Statistical comparison between groups was performed using 2-way ANOVA with Bonferroni's multiple comparisons test. Statistically significant values are indicated: ${ }^{*} p<0.05$ and ${ }^{* * *} p<0.001$. (F) Proportions of $\mathrm{CXCR}^{+}$cells in every mCD4 T-cell subset are plotted for each macaque. Six macaques have been tested for each group. Statistical comparison between groups was performed using 2-way ANOVA with Bonferroni's multiple comparisons test. Statistically significant values are indicated: ${ }^{* *} p<0.01$. Representative staining with $(\mathbf{G})$ CD8 and (H) CD68 Abs of spleen sections from one macaque of the TT group is shown in left panels. Mean numbers of positive cells per GC are plotted for each macaque (right panels). Scale Bar $=100 \mu \mathrm{m}$ (I) Graph represents the correlation between the number of CD68 ${ }^{+}$cells per GC and either the number of fCD8 per GC (left panel) or the percentages of $\mathrm{T}_{\mathrm{FH}}$ (right panel). Spearman rank test was used for statistical analyses. rho and $p$ values are given. Each dot represents mean value for one macaque from the $\mathrm{SIV}^{+}$ (open circle) or TT (black circle) group. (J) Representative staining with FOXP3 Ab of spleen sections from one macaque of the TT group is shown in left panel. GC and mantle zone are fixed by white dotted lines and FOXP3 ${ }^{+}$cells are indicated by red asterisks. Proportions of FOXP3 ${ }^{+}$cells in GC, follicle and T-cell area are plotted for each macaque. Scale Bar $=200 \mu \mathrm{m}$. (K) Ratio between numbers of $\mathrm{T}_{\mathrm{FH}}$ and $\mathrm{T}_{\mathrm{FR}}$ per GC was plotted for each macaque from Groups SIV ${ }^{+}$and TT. Statistical comparison between groups was performed using 2-way ANOVA with Bonferroni's multiple comparisons test. Statistically significant values are indicated: ${ }^{*} p<0.05$ and ${ }^{* *} p<0.01$. For $(\mathbf{A}, \mathbf{B}, \mathbf{G}, \mathbf{H}, \mathbf{K})$, bars represent Mean values of the group $\pm \mathrm{SD}$ and statistical comparison between groups was performed using the Mann Whitney non-parametric test. Statistically significant values are indicated: ${ }^{* *} p<0.01$ and ${ }^{* * *} p<0.001$. 


\subsection{BAFF-R and TACI Expression on GC B-Cells and $T_{F H}$}

A similar pattern of surface BAFF-R expression was observed on B-cells in both settings, with higher expression on MZ and RM B-cells compared to other B-cell subsets (Figure 6A). As we previously reported [17], the highest frequency of $\mathrm{TACI}^{+}$cells was found in RM B-cells, with intermediate frequencies on MZ, AM and TLM B-cells and less than $5 \%$ positive cells in naïve and GC B-cells (Figure 6B). Compared to the Group SIV ${ }^{+}$, expression of TACI was lower in all B-cell subsets from the Group TT, but a significant difference was only reached in RM B-cells. While in SIV-infected macaques BAFF-R and TACI were expressed by less than $1 \%$ of cells in the various subsets of mCD4 T-cells, all mCD4 T-cell subsets expressed higher level of BAFF-R in TT-vaccinated animals, with an average of $8.5 \%$ of BAFF- ${ }^{+}$cells among $\mathrm{T}_{\mathrm{FH}}$ cells (Figure $6 \mathrm{C}$ ). In the group TT, TACI was present on $2.1 \%$ and $3.9 \%$ of $\mathrm{T}_{\mathrm{FH}}$ and $\mathrm{PD} 1^{\text {int }}$ T-cells, respectively (Figure $6 \mathrm{D}$ ). This suggests that $\mathrm{T}_{\mathrm{FH}}$ and $\mathrm{PD} 1^{\text {int }}$ are responsive to BAFF during TT vaccination but lost this ability during SIV infection.

A
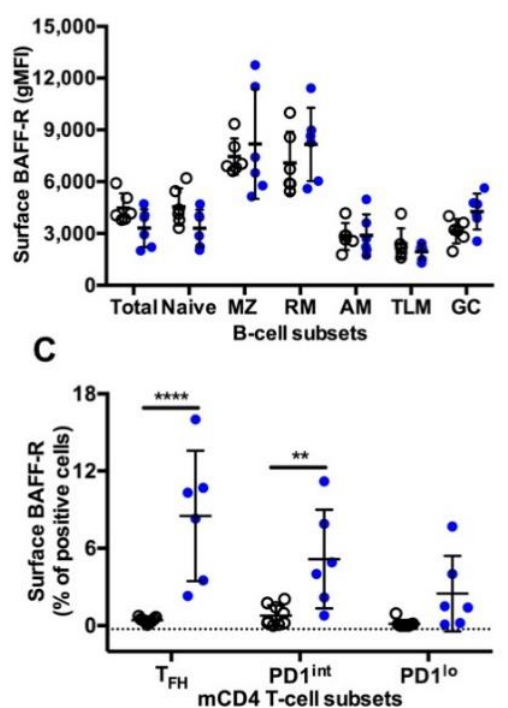

B
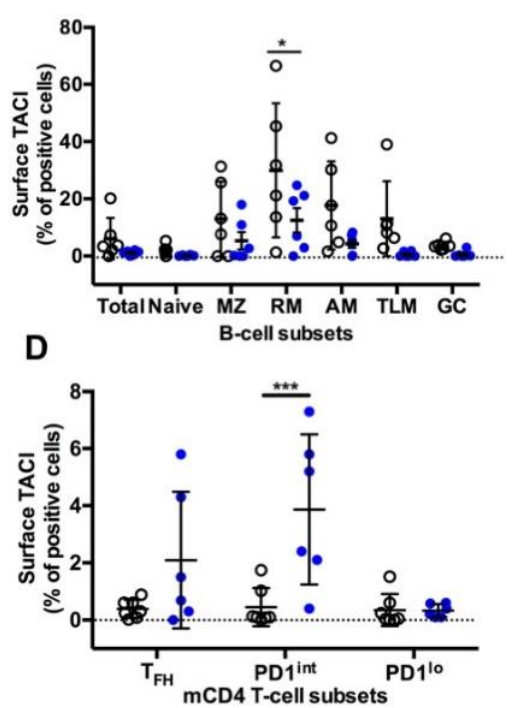

Figure 6. BAFF-R and TACI expression on splenic B-cells and mCD4 T-cell subsets from Groups SIV ${ }^{+}$ and TT. Surface expression of (A) BAFF-R (gMFI) (Table S3, Panel 5) and (B) TACI (\% of positive cells) (Table S3, Panel 6) was analysed in every B-cell subset from macaques of $\operatorname{SIV}^{+}(n=6)$ and TT $(n=6)$ groups. Surface expression of (C) BAFF-R (Table S3, Panel 7) and (D) TACI (Table S3, Panel 8) (\% of positive cells) was simultaneously determined in every mCD4 T-cell subset from macaques of $\operatorname{SIV}^{+}(n=9)$ and TT $(n=6)$ groups. Each dot represents one macaque from the $\mathrm{SIV}^{+}$(open circle) or TT (blue circle) group. Bars represent Mean \pm SD. Statistical comparison between groups was performed using 2-way ANOVA with Bonferroni's multiple comparisons test. Statistically significant values are indicated: ${ }^{*} p<0.05,{ }^{* *} p<0.01,{ }^{* * *} p<0.001$ and ${ }^{* * *} p<0.0001$.

\section{Discussion}

Our present data indicate that the extend of blood inflammation strongly differs between the two settings, mainly pro-inflammatory in SIV-infected macaques as previously reported $[17,51,52]$ but more restricted after primary and secondary immunization with TT. CXCL13 is considered as a reliable marker of GC activity [53] but its systemic levels remain globally low in our vaccinated macaques despite functional GC and substantial production of TT-specific IgG. Although modest, the rise in CXCL13 levels that occurred by days 7-10 post-prime in most macaques $(5-6 \mathrm{pg} / \mathrm{mL}, 40 \%$ over the pre-vaccination value, Figure S1) and by day $4 \mathrm{pb}(32 \mathrm{pg} / \mathrm{mL}, 60 \%$ over pre-boost value) might be physiologically significant. The kinetics and the magnitude of increase were consistent with those observed in healthy individuals vaccinated against Yellow Fever or with Adenovirus 5-vector encoding HIV-1 Env proteins, as well as in macaques after the second or third immunization with 
adjuvanted SIVmac Env protein [13]. In our hands, serum CXCL13 titers correlated with the frequencies of nodular $\mathrm{CD} 14^{\text {hi }}$ and $\mathrm{CD} 16^{+}$monocytes and spleen $\mathrm{T}_{\mathrm{FH}}$, suggesting that both $\mathrm{T}_{\mathrm{FH}}$ and monocytes could contribute to elevated CXCL13 blood levels. In SIV-infected macaques, we have previously shown that sorted $\mathrm{T}_{\mathrm{FH}}$ and PD1 ${ }^{\text {int }}$ produced CXCL13 and IL21 [17]. In line with $\mathrm{T}_{\mathrm{FH}}$ enhancing sequestration of GC B-cells through CXCL13 release, a positive correlation was observed between CXCL13 titers and frequencies of spleen GC B-cells $(r=0.4735, p<0.01)$. Conflicting results have been reported regarding CXCL13 as a predictive marker of bNAbs in various groups of HIV-infected individuals [53-57]. Although we did not assess the neutralizing activity of Abs in this study we found no correlation between levels of systemic CXCL13 and those of SIV-specific Abs or TT-specific IgG (data not shown).

It is now well established that neutrophils, myeloid cells and DC are potent sources of CXCL10 during various settings. CXCL10 titers were strongly elevated in SIV-infected macaques but not in TT-vaccinated macaques, with titers correlating with frequencies of CD14 ${ }^{\text {hi }}$ monocytes and total DC in LNs and spleen but also with frequencies of nodular $\mathrm{pDC}$ and numbers of macrophages $\left(\mathrm{CD}^{+} 8^{+}\right)$in spleen GC. Heightened levels of SIV-induced IFN $\alpha$ likely enhance CXCL10 and CXCL13 production by Ag-presenting cells. As previously suggested [58,59], CXCL10 produced by infiltrating monocytes and/or DC could synergize with CXCL13 to attract/sequester $\mathrm{T}_{\mathrm{FH}}$-about $70 \%$ of them expressing CXCR3 in our SIV-infected macaques-but also fCD8 in GC of SIV-infected macaques. Accordingly, numbers of fCD8 correlated with those of infiltrating macrophages, both numbers being significantly lower in the Group TT than in the Group SIV ${ }^{+}$. Numbers of fCD8 correlated with those of apoptotic cells in GC ( $r=0.737, p<0.02$, not shown) suggesting that fCD8 might exert cytolytic functions. $\mathrm{T}_{\mathrm{FR}}$ are more numerous in spleen GC of TT-vaccinated macaques with a $\mathrm{T}_{\mathrm{FH}} / \mathrm{T}_{\mathrm{FR}}$ ratio increased by 3.7-fold compared to the Group $\mathrm{SIV}^{+}$. A higher ratio might strengthen the selection of TT-specific B-cells with higher BCR affinity [20]. In agreement with data of Sayin et al. [60], we found that $\mathrm{T}_{\mathrm{FR}}$ preferentially reside at the border between B-cell follicle and T-cell area or between GC and mantle zone in both settings suggesting $\mathrm{T}_{\mathrm{FR}}$ can exert regulatory functions in $\mathrm{GC}$ but also on early activation of GC B-cell founders and pre- $\mathrm{T}_{\mathrm{FH}}$ at the outside border of follicle.

In agreement with data in healthy individuals revaccinated by TT [40,61], serum TT-specific IgG reached a plateau value at day $7 \mathrm{pb}$ in our TT-vaccinated macaques which is consistent with a rapid extrafollicular maturation of plasma blasts and/or memory B-cells into plasma cells [62]. With more than $80 \%$ proliferating cells in spleen and nodular GC B-cells from TT-vaccinated macaques, GC reaction was likely restarted by the boost, as indicated by the presence of PBs in spleen GC and high frequencies of plasma blasts/cells in lymph node at day $21 \mathrm{pb}$. A majority of spleen and LN memory B-cells exhibited a RM phenotype in TT-vaccinated macaques, while half of memory B-cells had a phenotype of AM B-cells in spleen from SIV-infected macaques. In agreement with data showing that T-bet $^{+} \mathrm{CD} 21^{\text {lo }}$ memory B-cells preferentially accumulate in extrafollicular areas of LN in chronically HIV-infected patients [39], most T-bet ${ }^{+}$cells (B- and T-cells) were localized outside GC in spleen from SIV-infected and TT-vaccinated macaques. Only rare T-bet ${ }^{+}$ cells were found in GC, even in SIV-infected macaques (data not shown). Splenic $\mathrm{T}_{\mathrm{FH}}$ in SIV-infected macaques simultaneously producing IFN $\gamma$ (this work and [17]) and viral Ags could license the generation of AM B-cells in GC, as suggested by others [30,39]. Moreover, spleen AM B-cells are less frequent in TT-vaccinated macaques, with less $\mathrm{T}_{\mathrm{FH}}$ expressing IFN $\gamma$. Supporting a link between IFN $\gamma$ production in GC and generation of AM B-cells, the frequencies of IFN $\gamma^{+}$in $\mathrm{T}_{\mathrm{FH}}$ correlated with those of AM B-cells in total B-cells $(r=0.90$, $p<0.0001$, not shown). In SIV-infected macaques, elevated proportions of AM and TLM Bcells unable to re-enter GC might lower affinity maturation of SIV-specific Abs. Contrasting with substantial accumulation of AM in spleen from SIV-infected macaques compared to TT-vaccinated macaques, proportions of AM were comparable in LNs for both settings. At least during acute infection, nodular AM B-cells could promptly exit into blood and 
transiently accumulate in spleen areas in close contact to blood (marginal zone or red pulp) due to different trafficking constraints.

The pattern of BAFF-R expression is comparable on B-cell subsets between the two settings, with a lower expression on GC and atypical memory B-cells. This latter result extends pioneer observations showing that BAFF-R expression is decreased on CD21 ${ }^{\text {lo }}$ blood B-cells in viremic HIV-infected patients, impairing their in vitro survival in response to BAFF [63]. However, the CD21 ${ }^{\text {lo }}$ population examined in this later paper was heterogenous including immature and mature B-cells and possibly plasma blasts/cells. In contrast to B-cells, mCD4 T-cells differently express BAFF-R in the two settings. Indeed, BAFF-R is absent from mCD4 T-cell subsets in SIV-infected macaques (this work and [17]), whereas it is expressed on $\mathrm{T}_{\mathrm{FH}}$ and, to a lesser extent, on PD1 ${ }^{\text {int }}$ and PD1 $1^{\text {lo }} \mathrm{mCD} 4$ T-cells in TT-vaccinated animals. A low percentage of $\mathrm{TACI}^{+}$cells is also found in these three subsets, suggesting that the low BAFF levels are insufficient at inducing the cleavage or internalization of BAFF receptor [64]. Expression of BAFF-R on circulating $\mathrm{T}_{\mathrm{FH}}$ has been previously reported in patients with lupus but was associated with increased BAFF levels [65]. Whereas BAFF/BAFF-R interactions induce IFN $\gamma$ release by $\mathrm{T}_{\mathrm{FH}}$ in lupus-prone mice, the production of IFN $\gamma$ by GC $\mathrm{T}_{\mathrm{FH}}$ was not modified by in vivo BAFF neutralization in SIV-infected macaques [17]. Thus BAFF- $R$ is differently expressed by $\mathrm{T}_{\mathrm{FH}}$ during response to a TD Ag or viral infections, and BAFF/BAFF-R interactions on $\mathrm{T}_{\mathrm{FH}}$ differently regulate IFN $\gamma$ in autoimmune and infection settings. In vaccine settings, BAFF produced at low levels in GC might nevertheless contribute to $\mathrm{T}_{\mathrm{FH}}$ physiology and GC reaction.

Thus, a compromised GC reaction and a potent inflammation characterize SIV infection compared to TT vaccination. In spleen and even in inguinal LNs, near the site of immunization, monocytes and DCs are less frequent in TT-vaccinated macaques than in SIV-infected ones, which probably results from $\mathrm{Ag}$ persistence and potent inflammation in the latter group. Spleen GC reaction is of higher magnitude in SIV-infected macaques but several impairments could limit the induction of a protective immunity. First, virusinduced CD4 T-cell loss might reduce the renewal of GC $\mathrm{T}_{\mathrm{FH}}$ and their ability to establish appropriate cognate interactions with GC B-cells at the border of follicles or thereafter in GC. Second, helper functions of $\mathrm{T}_{\mathrm{FH}}$ could be impaired by their polarization into $\mathrm{T}_{\mathrm{FH} 1^{-}}$ like, by inflammation-induced recruitment of fCD8 (either regulatory or cytotoxic) and by low numbers of $\mathrm{T}_{\mathrm{FR}}$ limiting $\mathrm{T}_{\mathrm{FH}} / \mathrm{T}_{\mathrm{FR}}$ competition for high affinity B-cells. Third, the IFN $\gamma$-enriched GC microenvironment likely favors accumulation of spleen AM B-cells that no more participate to the GC reaction and the Ab affinity maturation. Increased GC B-cells apoptosis might also contribute to eliminate SIV-specific B-cells. With GC B-cells expressing low levels of BAFF-R in both settings, it seems unlikely that BAFF contributes to their survival or selection. In contrast, BAFF-R and TACI being expressed by $\mathrm{T}_{\mathrm{FH}}$ in vaccinated macaques, BAFF might interfere with $\mathrm{T}_{\mathrm{FH}}$ physiology.

Supplementary Materials: The following are available online at https:/ /www.mdpi.com/1999-491 5/13/2/263/s1. Figure S1: Levels of Serum CXCL13 during TT-Immunization. Figure S2: Gating Strategy for the Identification of B-Cell Subsets in Lymphoid Organs. Figure S3: Gating Strategies for the Identification of Memory CD4 T-Cell Subsets. Table S1: MHC haplotypes of enrolled macaques. Table S2: Antibody Panels for Multiparameter Flow Cytometry. Table S3: Detection of BAFF Receptors on B- and T-cells by Flow Cytometry. Table S4: Antibodies for Immunohistochemistry.

Author Contributions: Conceptualization, Y.R.; Data curation, G.B. and Y.R.; Formal analysis, M.T., S.I. and G.B.; Funding acquisition, Y.R.; Investigation, M.T., H.M.I., S.I., R.L.G., N.B. and G.B.; Methodology, M.T., H.M.I., S.I. and G.B.; Project administration, Y.R.; Supervision, G.B. and Y.R.; Validation, G.B. and Y.R.; Visualization, Y.R.; Writing—original draft, M.T., H.M.I., S.I., G.B. and Y.R. All authors have read and agreed to the published version of the manuscript.

Funding: This work was supported by grants to YR from the "Agence Nationale de Recherches sur le SIDA et les Hépatites Virales" (ANRS). GB and MT were supported by postdoctoral fellowships from ANRS. HI was a visiting researcher supported by a fellowship from the French Institute in Egypt. This work was also supported by the "Investissements d'Avenir" programs managed by the 
ANR under reference ANR-11-INBS-0008, funding the Infectious Disease Models and Innovative Therapies (IDMIT, Fontenay-aux-Roses, France) infrastructure, and ANR-10-EQPX-02-01, funding the FlowCyTech facility (IDMIT, Fontenay-aux-Roses, France).

Institutional Review Board Statement: NHPs were handled in accordance to national regulations (Commisariat à l'Energie Atomique et aux Energies Alternatives (CEA) Permit Number A 92-32-02), in compliance with Standards for Human Care and Use of Laboratory of the Office for Laboratory Animal Welfare under Assurance number A5826-01, and the European Directive (2010/63, recommendation $\mathrm{N}^{\circ}$ ). The study was approved by the Ministère de l'Education Nationale, de l'Enseignement Supérieur et de la Recherche (France) and the Comité d’Ethique en Expérimentation Animale $\mathrm{n}^{\circ} 44$ under the reference 2015121509045664 (APAFIS\#3178).

Informed Consent Statement: Not Applicable.

Data Availability Statement: Not Applicable.

Acknowledgments: The authors would like to thank all members of the ASW and L2I groups of IDMIT. The authors also thank K. Bailly and P. Vallin from the CYBIO core facility as well as M. Favier, R. Onifarasoaniaina and F. Ely-Marius of the HisTIM core facility for their skillful technical assistance.

Conflicts of Interest: Authors declare no conflict of interest.

\section{References}

1. Moir, S.; Fauci, A.S. B-cell responses to HIV infection. Immunol. Rev. 2017, 275, 33-48. [CrossRef]

2. Chiodi, F.; Scarlatti, G. Editorial: HIV-induced damage of B cells and production of HIV neutralizing antibodies. Front. Immunol. 2018, 9, 297. [CrossRef]

3. Bannard, O.; Cyster, J.G. Germinal centers: Programmed for affinity maturation and antibody diversification. Curr. Opin. Immunol. 2017, 45, 21-30. [CrossRef] [PubMed]

4. Binder, S.C.; Meyer-Hermann, M. Implications of intravital imaging of murine germinal centers on the control of B cell selection and division. Front. Immunol. 2016, 7, 593. [CrossRef] [PubMed]

5. Victora, G.D.; Nussenzweig, M.C. Germinal centers. Annu. Rev. Immunol. 2012, 30, 429-457. [CrossRef] [PubMed]

6. Sanchez-Merino, V.; Fabra-Garcia, A.; Gonzalez, N.; Nicolas, D.; Merino-Mansilla, A.; Manzardo, C.; Ambrosioni, J.; Schultz, A.; Meyerhans, A.; Mascola, J.R.; et al. Detection of broadly neutralizing activity within the first months of HIV-1 infection. J. Virol. 2016, 90, 5231-5245. [CrossRef] [PubMed]

7. Borrow, P.; Moody, M.A. Immunologic characteristics of HIV-infected individuals who make broadly neutralizing antibodies. Immunol. Rev. 2017, 275, 62-78. [CrossRef]

8. Verkoczy, L.; Diaz, M. Autoreactivity in HIV-1 broadly neutralizing antibodies: Implications for their function and induction by vaccination. Curr. Opin. HIV AIDS 2014, 9, 224-234. [CrossRef] [PubMed]

9. Liao, H.X.; Chen, X.; Munshaw, S.; Zhang, R.; Marshall, D.J.; Vandergrift, N.; Whitesides, J.F.; Lu, X.; Yu, J.S.; Hwang, K.K.; et al. Initial antibodies binding to HIV-1 gp41 in acutely infected subjects are polyreactive and highly mutated. J. Exp. Med. 2011, 208, 2237-2249. [CrossRef] [PubMed]

10. Burton, D.R.; Mascola, J.R. Antibody responses to envelope glycoproteins in HIV-1 infection. Nat. Immunol. 2015, 16, 571-576. [CrossRef]

11. Schroeder, K.M.S.; Agazio, A.; Strauch, P.J.; Jones, S.T.; Thompson, S.B.; Harper, M.S.; Pelanda, R.; Santiago, M.L.; Torres, R.M. Breaching peripheral tolerance promotes the production of HIV-1-neutralizing antibodies. J. Exp. Med. 2017, 214, $2283-2302$. [CrossRef]

12. Lee, J.H.; Ozorowski, G.; Ward, A.B. Cryo-em structure of a native, fully glycosylated, cleaved HIV-1 envelope trimer. Science 2016, 351, 1043-1048. [CrossRef]

13. Havenar-Daughton, C.; Carnathan, D.G.; Torrents de la Pena, A.; Pauthner, M.; Briney, B.; Reiss, S.M.; Wood, J.S.; Kaushik, K.; van Gils, M.J.; Rosales, S.L.; et al. Direct probing of germinal center responses reveals immunological features and bottlenecks for neutralizing antibody responses to HIV env trimer. Cell Rep. 2016, 17, 2195-2209. [CrossRef]

14. Pauthner, M.; Havenar-Daughton, C.; Sok, D.; Nkolola, J.P.; Bastidas, R.; Boopathy, A.V.; Carnathan, D.G.; Chandrashekar, A.; Cirelli, K.M.; Cottrell, C.A.; et al. Elicitation of robust tier 2 neutralizing antibody responses in nonhuman primates by HIV envelope trimer immunization using optimized approaches. Immunity 2017, 46, 1073-1088.e1076. [CrossRef] [PubMed]

15. Pauthner, M.G.; Nkolola, J.P.; Havenar-Daughton, C.; Murrell, B.; Reiss, S.M.; Bastidas, R.; Prevost, J.; Nedellec, R.; von Bredow, B.; Abbink, P.; et al. Vaccine-induced protection from homologous tier 2 SHIV challenge in nonhuman primates depends on serumneutralizing antibody titers. Immunity 2019, 50, 241-252.e6. [CrossRef] [PubMed]

16. Muir, R.; Metcalf, T.; Tardif, V.; Takata, H.; Phanuphak, N.; Kroon, E.; Colby, D.J.; Trichavaroj, R.; Valcour, V.; Robb, M.L.; et al. Altered memory circulating T follicular helper-B cell interaction in early acute hiv infection. PLoS Pathog. 2016, 12, e1005777. [CrossRef] [PubMed] 
17. Borhis, G.; Trovato, M.; Ibrahim, H.M.; Isnard, S.; Le Grand, R.; Bosquet, N.; Richard, Y. Impact of BAFF blockade on inflammation, germinal center reaction and effector B-cells during acute siv infection. Front. Immunol. 2020, 11, 252. [CrossRef]

18. Perreau, M.; Savoye, A.L.; De Crignis, E.; Corpataux, J.M.; Cubas, R.; Haddad, E.K.; De Leval, L.; Graziosi, C.; Pantaleo, G. Follicular helper $\mathrm{t}$ cells serve as the major CD4 T cell compartment for HIV-1 infection, replication, and production. J. Exp. Med. 2013, 210, 143-156. [CrossRef]

19. Fukazawa, Y.; Lum, R.; Okoye, A.A.; Park, H.; Matsuda, K.; Bae, J.Y.; Hagen, S.I.; Shoemaker, R.; Deleage, C.; Lucero, C.; et al. B cell follicle sanctuary permits persistent productive simian immunodeficiency virus infection in elite controllers. Nat. Med. 2015, 21, 132-139. [CrossRef]

20. Linterman, M.A.; Pierson, W.; Lee, S.K.; Kallies, A.; Kawamoto, S.; Rayner, T.F.; Srivastava, M.; Divekar, D.P.; Beaton, L.; Hogan, J.J.; et al. Foxp3+ follicular regulatory T cells control the germinal center response. Nat. Med. 2011, 17, 975-982. [CrossRef] [PubMed]

21. Fan, W.; Demers, A.J.; Wan, Y.; Li, Q. Altered ratio of T follicular helper cells to T follicular regulatory cells correlates with autoreactive antibody response in simian immunodeficiency virus-infected rhesus macaques. J. Immunol. 2018, 200, 3180-3187. [CrossRef]

22. Laidlaw, B.J.; Lu, Y.; Amezquita, R.A.; Weinstein, J.S.; Vander Heiden, J.A.; Gupta, N.T.; Kleinstein, S.H.; Kaech, S.M.; Craft, J. Interleukin-10 from CD4(+) follicular regulatory T cells promotes the germinal center response. Sci. Immunol. 2017,2 , eaan4767. [CrossRef]

23. Xie, M.M.; Dent, A.L. Unexpected help: Follicular regulatory T cells in the germinal center. Front. Immunol. 2018, 9, 1536. [CrossRef]

24. Miller, S.M.; Miles, B.; Guo, K.; Folkvord, J.; Meditz, A.L.; McCarter, M.D.; Levy, D.N.; MaWhinney, S.; Santiago, M.L.; Connick, E. Follicular regulatory T cells are highly permissive to R5-tropic HIV-1. J. Virol. 2017, 91, e00430-17. [CrossRef]

25. Bronnimann, M.P.; Skinner, P.J.; Connick, E. The B-cell follicle in HIV infection: Barrier to a cure. Front. Immunol. 2018, 9, 20. [CrossRef] [PubMed]

26. Karnell, J.L.; Kumar, V.; Wang, J.; Wang, S.; Voynova, E.; Ettinger, R. Role of CD11c(+) T-bet(+) B cells in human health and disease. Cell Immunol. 2017, 321, 40-45. [CrossRef] [PubMed]

27. Obeng-Adjei, N.; Portugal, S.; Holla, P.; Li, S.; Sohn, H.; Ambegaonkar, A.; Skinner, J.; Bowyer, G.; Doumbo, O.K.; Traore, B.; et al. Malaria-induced interferon-gamma drives the expansion of Tbethi atypical memory B cells. PLoS Pathog. 2017, 13, e1006576. [CrossRef] [PubMed]

28. Jenks, S.A.; Cashman, K.S.; Zumaquero, E.; Marigorta, U.M.; Patel, A.V.; Wang, X.; Tomar, D.; Woodruff, M.C.; Simon, Z.; Bugrovsky, R.; et al. Distinct effector B cells induced by unregulated toll-like receptor 7 contribute to pathogenic responses in systemic lupus erythematosus. Immunity 2018, 49, 725-739 e726. [CrossRef]

29. Knox, J.J.; Buggert, M.; Kardava, L.; Seaton, K.E.; Eller, M.A.; Canaday, D.H.; Robb, M.L.; Ostrowski, M.A.; Deeks, S.G.; Slifka, M.K.; et al. T-bet+ B cells are induced by human viral infections and dominate the hiv gp140 response. JCI Insight 2017, 2, 92943. [CrossRef] [PubMed]

30. Rubtsova, K.; Rubtsov, A.V.; van Dyk, L.F.; Kappler, J.W.; Marrack, P. T-box transcription factor T-bet, a key player in a unique type of B-cell activation essential for effective viral clearance. Proc. Natl. Acad. Sci. USA 2013, 110, E3216-E3224. [CrossRef]

31. Siewe, B.; Nipper, A.J.; Sohn, H.; Stapleton, J.T.; Landay, A. FcRL4 expression identifies a pro-inflammatory B cell subset in viremic hiv-infected subjects. Front. Immunol. 2017, 8, 1339. [CrossRef]

32. Portugal, S.; Tipton, C.M.; Sohn, H.; Kone, Y.; Wang, J.; Li, S.; Skinner, J.; Virtaneva, K.; Sturdevant, D.E.; Porcella, S.F.; et al. Malaria-associated atypical memory B cells exhibit markedly reduced B cell receptor signaling and effector function. Elife 2015, 4, e07218. [CrossRef]

33. Moir, S.; Fauci, A.S. Insights into B cells and HIV-specific B-cell responses in HIV-infected individuals. Immunol. Rev. 2013, 254, 207-224. [CrossRef] [PubMed]

34. Borhis, G.; Richard, Y. Subversion of the B-cell compartment during parasitic, bacterial, and viral infections. BMC Immunol. 2015, 16, 15. [CrossRef] [PubMed]

35. Perez-Mazliah, D.; Gardner, P.J.; Schweighoffer, E.; McLaughlin, S.; Hosking, C.; Tumwine, I.; Davis, R.S.; Potocnik, A.J.; Tybulewicz, V.L.; Langhorne, J. Plasmodium-specific atypical memory B cells are short-lived activated B cells. Elife 2018, 7, e39800. [CrossRef] [PubMed]

36. Kardava, L.; Moir, S.; Shah, N.; Wang, W.; Wilson, R.; Buckner, C.M.; Santich, B.H.; Kim, L.J.; Spurlin, E.E.; Nelson, A.K.; et al. Abnormal B cell memory subsets dominate HIV-specific responses in infected individuals. J. Clin. Investig. 2014, 124, 3252-3262. [CrossRef]

37. Titanji, K.; Velu, V.; Chennareddi, L.; Vijay-Kumar, M.; Gewirtz, A.T.; Freeman, G.J.; Amara, R.R. Acute depletion of activated memory B cells involves the PD-1 pathway in rapidly progressing SIV-infected macaques. J. Clin. Investig. 2010, 120, 3878-3890. [CrossRef]

38. Lau, D.; Lan, L.Y.; Andrews, S.F.; Henry, C.; Rojas, K.T.; Neu, K.E.; Huang, M.; Huang, Y.; DeKosky, B.; Palm, A.E.; et al. Low CD21 expression defines a population of recent germinal center graduates primed for plasma cell differentiation. Sci. Immunol. 2017, 2, eaai8153. [CrossRef] 
39. Austin, J.W.; Buckner, C.M.; Kardava, L.; Wang, W.; Zhang, X.; Melson, V.A.; Swanson, R.G.; Martins, A.J.; Zhou, J.Q.; Hoehn, K.B.; et al. Overexpression of T-bet in HIV infection is associated with accumulation of B cells outside germinal centers and poor affinity maturation. Sci. Transl. Med. 2019, 11, eaax0904. [CrossRef]

40. Giesecke, C.; Frolich, D.; Reiter, K.; Mei, H.E.; Wirries, I.; Kuhly, R.; Killig, M.; Glatzer, T.; Stolzel, K.; Perka, C.; et al. Tissue distribution and dependence of responsiveness of human antigen-specific memory B cells. J. Immunol. 2014, 192, 3091-3100. [CrossRef]

41. Livingston, K.A.; Jiang, X.; Stephensen, C.B. CD4 T-helper cell cytokine phenotypes and antibody response following tetanus toxoid booster immunization. J. Immunol. Methods 2013, 390, 18-29. [CrossRef]

42. Pallikkuth, S.; De Armas, L.R.; Pahwa, R.; Rinaldi, S.; George, V.K.; Sanchez, C.M.; Pan, L.; Dickinson, G.; Rodriguez, A.; Fischl, M.; et al. Impact of aging and hiv infection on serologic response to seasonal influenza vaccination. AIDS 2018, 32, 1085-1094. [CrossRef]

43. Parmigiani, A.; Alcaide, M.L.; Freguja, R.; Pallikkuth, S.; Frasca, D.; Fischl, M.A.; Pahwa, S. Impaired antibody response to influenza vaccine in hiv-infected and uninfected aging women is associated with immune activation and inflammation. PLoS ONE 2013, 8, e79816. [CrossRef]

44. Le Grand, R.; Clayette, P.; Noack, O.; Vaslin, B.; Theodoro, F.; Michel, G.; Roques, P.; Dormont, D. An animal model for antilentiviral therapy: Effect of zidovudine on viral load during acute infection after exposure of macaques to simian immunodeficiency virus. AIDS Res. Hum. Retrovir. 1994, 10, 1279-1287. [CrossRef] [PubMed]

45. Peruchon, S.; Chaoul, N.; Burelout, C.; Delache, B.; Brochard, P.; Laurent, P.; Cognasse, F.; Prevot, S.; Garraud, O.; Le Grand, R.; et al. Tissue-specific B-cell dysfunction and generalized memory B-cell loss during acute SIV infection. PLoS ONE 2009, 4, e5966. [CrossRef] [PubMed]

46. Chaoul, N.; Burelout, C.; Peruchon, S.; van Buu, B.N.; Laurent, P.; Proust, A.; Raphael, M.; Garraud, O.; Le Grand, R.; Prevot, S.; et al. Default in plasma and intestinal IgA responses during acute infection by simian immunodeficiency virus. Retrovirology 2012, 9, 43. [CrossRef] [PubMed]

47. Li, G.; Cheng, M.; Nunoya, J.; Cheng, L.; Guo, H.; Yu, H.; Liu, Y.J.; Su, L.; Zhang, L. Plasmacytoid dendritic cells suppress HIV-1 replication but contribute to HIV-1 induced immunopathogenesis in humanized mice. PLoS Pathog. 2014, 10, e1004291. [CrossRef]

48. Hogenesch, H. Mechanism of immunopotentiation and safety of aluminum adjuvants. Front. Immunol. 2012, 3, 406. [CrossRef] [PubMed]

49. Lu, F.; Hogenesch, H. Kinetics of the inflammatory response following intramuscular injection of aluminum adjuvant. Vaccine 2013, 31, 3979-3986. [CrossRef]

50. Cohen, K.W.; Dugast, A.S.; Alter, G.; McElrath, M.J.; Stamatatos, L. HIV-1 single-stranded rna induces CXCL13 secretion in human monocytes via TLR7 activation and plasmacytoid dendritic cell-derived type I IFN. J. Immunol. 2015, 194, 2769-2775. [CrossRef]

51. Stacey, A.R.; Norris, P.J.; Qin, L.; Haygreen, E.A.; Taylor, E.; Heitman, J.; Lebedeva, M.; DeCamp, A.; Li, D.; Grove, D.; et al. Induction of a striking systemic cytokine cascade prior to peak viremia in acute human immunodeficiency virus type 1 infection, in contrast to more modest and delayed responses in acute hepatitis B and C virus infections. J. Virol. 2009, 83, 3719-3733. [CrossRef]

52. Liovat, A.S.; Rey-Cuille, M.A.; Lecuroux, C.; Jacquelin, B.; Girault, I.; Petitjean, G.; Zitoun, Y.; Venet, A.; Barre-Sinoussi, F.; Lebon, P.; et al. Acute plasma biomarkers of T cell activation set-point levels and of disease progression in HIV-1 infection. PLoS ONE 2012, 7, e46143. [CrossRef] [PubMed]

53. Havenar-Daughton, C.; Lindqvist, M.; Heit, A.; Wu, J.E.; Reiss, S.M.; Kendric, K.; Belanger, S.; Kasturi, S.P.; Landais, E.; Akondy, R.S.; et al. CXCL13 is a plasma biomarker of germinal center activity. Proc. Natl. Acad. Sci. USA 2016, 113, $2702-2707$. [CrossRef] [PubMed]

54. Mabuka, J.M.; Dugast, A.S.; Muema, D.M.; Reddy, T.; RamLakhan, Y.; Euler, Z.; Ismail, N.; Moodley, A.; Dong, K.L.; Morris, L.; et al. Plasma CXCL13 but not B cell frequencies in acute HIV infection predicts emergence of cross-neutralizing antibodies. Front. Immunol. 2017, 8, 1104. [CrossRef]

55. Roider, J.; Porterfield, J.Z.; Ogongo, P.; Muenchhoff, M.; Adland, E.; Groll, A.; Morris, L.; Moore, P.L.; Ndung'u, T.; Kloverpris, H.; et al. Plasma IL-5 but not CXCL13 correlates with neutralization breadth in HIV-infected children. Front. Immunol. 2019, 10, 1497. [CrossRef] [PubMed]

56. Mehraj, V.; Ramendra, R.; Isnard, S.; Dupuy, F.P.; Lebouche, B.; Costiniuk, C.; Thomas, R.; Szabo, J.; Baril, J.G.; Trottier, B.; et al. CXCL13 as a biomarker of immune activation during early and chronic HIV infection. Front. Immunol. 2019, 10, 289. [CrossRef]

57. Richardson, S.I.; Chung, A.W.; Natarajan, H.; Mabvakure, B.; Mkhize, N.N.; Garrett, N.; Abdool Karim, S.; Moore, P.L.; Ackerman, M.E.; Alter, G.; et al. HIV-specific Fc effector function early in infection predicts the development of broadly neutralizing antibodies. PLoS Pathog. 2018, 14, e1006987. [CrossRef]

58. Ferrando-Martinez, S.; Moysi, E.; Pegu, A.; Andrews, S.; Nganou Makamdop, K.; Ambrozak, D.; McDermott, A.B.; Palesch, D.; Paiardini, M.; Pavlakis, G.N.; et al. Accumulation of follicular CD8+ T cells in pathogenic siv infection. J. Clin. Investig. 2018, 128, 2089-2103. [CrossRef]

59. Miles, B.; Miller, S.M.; Connick, E. CD4 T follicular helper and regulatory cell dynamics and function in HIV infection. Front. Immunol. 2016, 7, 659. [CrossRef] 
60. Sayin, I.; Radtke, A.J.; Vella, L.A.; Jin, W.; Wherry, E.J.; Buggert, M.; Betts, M.R.; Herati, R.S.; Germain, R.N.; Canaday, D.H. Spatial distribution and function of T follicular regulatory cells in human lymph nodes. J. Exp. Med. 2018, 215, 1531-1542. [CrossRef]

61. Frolich, D.; Giesecke, C.; Mei, H.E.; Reiter, K.; Daridon, C.; Lipsky, P.E.; Dorner, T. Secondary immunization generates clonally related antigen-specific plasma cells and memory B cells. J. Immunol. 2010, 185, 3103-3110. [CrossRef] [PubMed]

62. Paus, D.; Phan, T.G.; Chan, T.D.; Gardam, S.; Basten, A.; Brink, R. Antigen recognition strength regulates the choice between extrafollicular plasma cell and germinal center B cell differentiation. J. Exp. Med. 2006, 203, 1081-1091. [CrossRef] [PubMed]

63. Moir, S.; Malaspina, A.; Pickeral, O.K.; Donoghue, E.T.; Vasquez, J.; Miller, N.J.; Krishnan, S.R.; Planta, M.A.; Turney, J.F.; Justement, J.S.; et al. Decreased survival of B cells of HIV-viremic patients mediated by altered expression of receptors of the TNF superfamily. J. Exp. Med. 2004, 200, 587-599. [CrossRef]

64. Schweighoffer, E.; Vanes, L.; Nys, J.; Cantrell, D.; McCleary, S.; Smithers, N.; Tybulewicz, V.L. The BAFF receptor transduces survival signals by co-opting the B cell receptor signaling pathway. Immunity 2013, 38, 475-488. [CrossRef] [PubMed]

65. Coquery, C.M.; Loo, W.M.; Wade, N.S.; Bederman, A.G.; Tung, K.S.; Lewis, J.E.; Hess, H.; Erickson, L.D. BAFF regulates follicular helper T cells and affects their accumulation and interferon-gamma production in autoimmunity. Arthritis Rheumatol. 2015, 67, 773-784. [CrossRef] 